\title{
Extremadura: Behind the material traces of Franco's repression
}

\author{
Laura Muñoz Encinar and Julián Chaves Palacios \\ Universidad de Extremadura, Facultad de Filosofía y Letras, Campus Universitario. \\ Avd. Universidad s/n C.P 10004 Cáceres. España \\ e-mail: 1munozencinar@unex.es
}

Submitted: 20 October 2014. Accepted: 31 October 2014

\begin{abstract}
After the failed coup d'état of July 17 1936 and after the start of the Spanish Civil War that followed it, rebels carried out a repressive strategy based on the execution of thousands of people as a key tool of social control. The socialization of fear and terror through humiliation, killing and disappearance would become the main strategy employed throughout the war and the post-war period. In this context, perpetrators would exercise repressive practices on victims and their bodies. As a result, countless mass graves were opened in order to hide the bodies of victims. In the region of Extremadura, these mass graves have been investigated through the application of archeology and physical anthropology as disciplines of research and historical knowledge production. The exhumations, have given us a diachronic point of view of the repressive strategies developed, associated with different contexts between 1936 and 1946. Analyses of mass executions linked to rebels' occupation of territories in this region, systematic rearguard killings in occupied areas, elimination procedures carried out in concentration camps and prisons and the fight against the armed guerrilla during the dictatorship, are the main contributions of this article.
\end{abstract}

KEYWORDS: Civil war; Francoism; material culture; mass graves; repression; historical knowledge

Citation / Cómo citar este artículo: Muñoz Encinar, Laura and Chaves Palacios, Julián (2014). "Extremadura: Behind the material traces of Franco's repression". Culture \& History Digital Journal, 3(2): e020. doi: http://dx.doi.org/10.3989/ chdj.2014.020

RESUMEN: Extremadura: Tras las huellas materiales de la represión franquista.- Tras el fracaso del golpe de Estado del 17 de julio de 1936 y el inicio de la Guerra Civil en España, se llevó a cabo, por parte de los sublevados, una estrategia represiva basada en la ejecución de miles de personas como principal herramienta de control social. La socialización del miedo y el terror a través de las vejaciones, ejecuciones y desapariciones será la principal estrategia utilizada, donde el uso de las víctimas y los cuerpos formará también parte de las prácticas represivas ideadas por los perpetradores. Como consecuencia, se abrieron incontables fosas comunes con el objetivo de ocultar los cadáveres de los represaliados. Estas fosas han sido investigadas en la Comunidad Autónoma de Extremadura desde la arqueología y antropología física como disciplinas de investigación y conocimiento histórico. Las exhumaciones nos han aportado una visión diacrónica de las estrategias represivas desarrolladas, asociadas a distintos contextos comprendidos entre 1936 y 1946. El análisis de las ejecuciones masivas vinculadas a la ocupación del territorio por las tropas golpistas, eliminaciones sistemáticas de civiles en poblaciones de retaguardia, procedimientos eliminatorios asociados a campos de concentración y prisiones así como la lucha contra la guerrilla armada durante el Primer Franquismo, son las principales contribuciones aportadas en este artículo.

PALABRAS CLAVE: Guerra civil; franquismo; cultura material; fosas comunes; represión; conocimiento histórico

Copyright: (C) 2014 CSIC This is an open-access article distributed under the terms of the Creative Commons AttributionNon Commercial (by-nc) Spain 3.0 License. 


\section{INTRODUCTION}

Archaeology is defined as the science that studies the past through its material remains. Employing this definition of the discipline, in this article, we will put forth a study of our more recent traumatic past, particularly those periods that correspond to the Spanish Civil War and the first part of Francisco Franco's dictatorship. The material traces from Franco's regime are wide and extensive. From an archaeological point of view, this materiality includes all of the human and non-human remains generated by the armed conflict and the subsequent authoritarian regime. They are tangible reminders that will allow us to analyze empirically the repression that was experienced in Spain during these two time periods.

One of the most obvious material traces of Francoist forms of violence are the mass graves and the material remains that can be found within them: the bodies and the objects associated with them. As a whole, examining these material traces and the context in which they appear allows us to reflect on acts of repression while also allowing us to reconstruct past events.

By analyzing exhumations through archaeological theory and method, we can reconstruct empirically the repression that victims suffered. Archaeological practice, including the physical analysis of human remains, allows us to understand this repressive apparatus, from the moment of a victim's arrest to the present. The way in which victims' bodies were treated in these contexts is part of the repressive apparatus devised by the perpetrators. With this type of analysis, we can obtain evidence that help us make inferences regarding the unlawful, repressive practices deployed in specific historical moments. It makes it possible to understand and analyze repressive strategies within the social and political context in which they occurred. We understand exhumations as processes of historical knowledge production, in which the recuperation of materials from mass graves must be interrelated with other contextual elements in order to obtain as much information as possible.

In this paper we present an analysis of the repressive strategies carried out during the Civil War and the first years of Franco dictatorship in the Extremadura region in Spain, providing a detailed study of different mass graves that correspond to different repressive contexts. First, we will provide general, quantative information regarding exhumations conducted before and during 2013. We will proceed by discussing five significant case studies from this time period. In each of the five cases, we analyze Francoist repression through the archaeological and forensic examination of mortal remains. The cases analyzed exemplify the main repressive phases carried out by the rebels during the Civil War and the dictatorship that followed it in this particular geographic region.

\section{THEORETICAL FRAMEWORK AND METHODOLOGY}

In archaeology and forensic archaeology we examine mass graves through a conceptual lens that considers "material remains" to be forms of evidence or proof (Crossland, 2013), which in our case relate to Francoist violence.

The exhaustive process of documenting of data first provides us with information about a particular act of repression and the context in which it took place. Secondly, we compare and contextualize this data in relationship to the material traces generated by the dictatorship. The diachronic analysis of this data, allows us to make inferences about the general patterns of behavior developed by the Francoist repressive apparatus over time. The presence of these material remains allows us to reveal what happened in the past. However, the absence of evidence also reveals important data regarding a particular event. In other words, the absence of evidence is not evidence of absence.

In discussing the concept of evidence, some authors examine ideas regarding intentionality, where evidence is always "of or for something" (Daston 1994; Csordas, 2004). Intentionality is a particularly interesting issue when examining mass graves, especially considering the transcendence of intentionality in the development of strategic plans to eliminate and exterminate one's enemy.

The study of repressive strategies during the Franco regime is entangled with the most legal and humanitarian objectives of this research: to prove that crimes against humanity have, in fact, taken place. In order to reach these objectives, we must provide evidence regarding the existence of generalized or systematic attacks against civilians and connect them to a systematic plan designed to eliminate a particular sector of the population.

Taking into account these points, in this paper we seek to pose key questions related to our field of study. This will provide a starting point for our analysis. We start with the following questions: How can we make inferences regarding the broader repressive strategies used by perpetrators during the Civil War and the ensuing dictatorship through an examination of particular case studies that correspond to mass executions that took place in specific geographic locations and at different points in time? Are these practices part of a directed, systematic plan sought to eliminate a particular sector of society? Can the archaeological study of mass graves or the archaeological analysis of different registers regarding mass violence allow us to prove the existence of intentional and systematized forms of repression? How can this kind of approach allow us to generate historical knowledge?

In order to answer these questions, we will analyze the archaeological evidence of mass graves in relationship to the context in which this evidence was originally generated. In doing so, we seek to provide an integrated view of repression that takes into consideration the cultural landscapes of war and dictatorship in their various facets: battlefields, fortifications, traces of conflicts found in urban contexts, concentration camps, prisons, social housing, cities and towns rebuilt after the war, fascist architecture, etc. (González-Ruibal, 2008: 19).

In this sense, the so-called Archaeology of the Civil War or Archaeology of Memory has been of great importance in recent years. These sub-disciplines attempt to 
show the connections between places, artifacts and people, and between different pasts and presents, taking into account four main aspects: landscape, processes over time, material culture and memory and the relationships between them (González-Ruibal, 2007: 216; Ayán, 2008: 232). In order to analyze mass graves approached from an archaeological or a physical-anthropological perspective, the data extracted from them must be interpreted in a framework that approaches the analysis of repression from an interdisciplinary standpoint.

Methodologically, the search for and identification of missing persons and the research discussed in this paper follow the Protocol Concerning the Exhumation of Victims of the Spanish Civil War and the Dictatorship in the BOE, or the Official Sate Newsletter, on September $27^{\text {th }}$, 2011. ${ }^{1}$ Various scientific disciplines are implicated in this protocol, which outlines the following research phases: (1) research in archives and other documentary collections of records; (2) the collection of oral testimonies, (3) the archaeological location, excavation and exhumation of mass graves; (4) the anthropological and forensic analysis of human remains and other forms of material extracted from graves; (5) DNA analysis of human remains in those cases where they are being analyzed via anthropological and/or forensic methods (6) the redaction of technical reports and (7) the reburial of the remains.

The research conducted before an archaeological intervention aims to develop lists of missing persons and to collect information about particular these disappearances and the historical context in which they occurred. This research phase also provides specific information about the missing person, such as their physical traits, possible illnesses that they suffered in life, and the clothing and personal belongings that he or she was carrying at the moment of his or her disappearance.

When searching for missing persons, in most cases the location of the mass graves is often known thanks to the information provided by oral testimonies. This knowledge is often provided by people who saw or had firsthand knowledge of a grave's location or people who heard about their existence through other sources. In sum, the historical and memory-based testimonies from the community where the disappearances occurred are key.

The location, excavation and exhumation of mass graves are completed through the rigorous application of scientific archaeological practices that aim to document everything found within the deposits and to draw conclusions about these materials. A systematic archaeological intervention requires a methodology and modes of excavation that aim to meticulously record all those variables that characterize the context in which the bodies of the missing were deposited and the stratigraphic sequence of the grave. In addition, the intervention requires that all skeletal remains and artifacts recovered from the site be identified and their spatial orientation, distribution and contextualization be noted (Muñoz-Encinar y García, 2010: 58).

The excavation method implemented in the cases described below used Harris' principle of stratigraphic units
(1991), as well as the registration and documentation of archaeological features and their spatial distribution. The application of an excavation method that combines both vertical and horizontal readings of the area being excavated with an examination of the relationships between objects, allows us to perform a detailed analysis of all of the parts that make up mass graves.

The main focus of the intervention is, firstly, the documentation of stratigraphic units that correspond with how the mass grave was brought into being: anthropic activities related to the excavation of the deposit, the burial of individuals and the concealment of corpses. Secondly, we look how elements inside the grave are arranged and their associations by situating individual corpses as the main points of reference and analysis (Muñoz-Encinar and García, 2010: 58-59).

In following this methodology, we first consider the location of the mass grave and the morphology of the deposit. Here we consider aspects such as the mass grave's spatial orientation, its disposition and its relationship with the surrounding landscape, the environment and other material elements generated by the Civil War and the dictatorship. In doing so, we can identify the type of deposit being analyzed and the relationship between its morphology and subsequent use. This, in turn, helps us identify the context in which the disappearances occurred. By observing these variables, we introduce concepts such as planning, systematicity and recurrence in assessing the use of mass graves and spaces of disappearance as a reflection of the repressive practices deployed by the perpetrators.

With regard to the formation of deposits (mass graves), it is also necessary to assess the post-depositional processes and their relationship to the development of these repressive practices. After bodies have been buried in a mass grave, they undergo different types of post-depositional processes, which are determined by the type of agents involved. So, if an anthropic agent is involved, we refer to those practices, such as the burning of corpses or their exposure for extended periods of time, that were employed after the bodies were deposited in the grave. It is also important to take into consideration the fosil-diagenetic characteristics of the deposit that may have affected the conservation of the remains after the burial and that may be varied: temperature, humidity, acidity of the sediment, chemical corrosion, roots, etc. In this sense, a deposit's location, its central characteristics or type and it subsequent evolution directly and decisively affect how bones and archaeological remains are conserved.

The aspects that will be examined below approach individual corpse and its relationship with other bodies and elements of the deposit as a point of reference. In this phase of the analysis, the main variables considered are the stratigraphic sequence (i.e. the accumulation of corpses in the grave), the position and orientation of the body and the position of the individual's limbs. We can assess again aspects regarding the prediction, planning or systematicity of repressive strategies and models that were by analyzing the data and patterns observed. 
The bodies found inside the mass graves are studied in relation to the objects they carried with them at the time of death, as well as in relation to the items linked to the acts of repression they suffered, such as ammunition or other objects associated with the perpetrators. We differentiate three categories of objects: objects related to clothing, personal possessions and elements related to the perpetrators.

The study and analysis of these objects allows us to develop individual profiles that provide us with information regarding how they dressed, their habits, their personal or political beliefs, and marital status, etc. This data can also be of great importance in the task of identifying remains. In addition, when we consider all of these elements together, we can observe the levels of homogeneity or difference among the group of individuals found in the mass grave, and from there develop theories regarding their possible origin and the context to which they belong.

Moreover, the objects associated with specific acts of repression give us information about the type of weapon used, the factory that supplied that particular weapon, the place where the executions were carried out and the context in which they were used. They allows us to identify if the perpetrators of these executions where members of military or paramilitary groups.

The anthropological and forensic analysis of the bodies provides us with the next large group of information. From this data, we can infer victims' age at death, sex, height and health, as well as their cause of death and the possible circumstances that surrounded it. The analysis of these variables aids us in the identification of the individual bodies and in the production of knowledge about the cause and circumstances surrounding their deaths. It also helps us to identify the repressive strategy used in each case.

\section{FIELD OF STUDY AND HISTORICAL CONTEXT}

Our research was conducted in Extremadura, a region of Spain located in the southwest area of the country, on the border with Portugal. This region includes two provinces, each of which was marked by distinct contexts, evolution and political behavior from the moment of the coup of July $17^{\text {th }}, 1936$ and onwards.

In the province of Cáceres, the support of the coup was almost immediate. The province's population backed the uprising since July 18 ${ }^{\text {th }}$ (Chaves, 1997: 22). In the twenty-four hours that followed, other important cities from the north part of the region, such as Plasencia and Coria, also expressed their support. In the following days, the province gradually came under the control of the rebels except for some areas in the east, which resisted the uprising until August 1936 (Chaves, 1997:24). After the first two months of the war, the entire territory of Cáceres, except for the town of Alía, was under the rebels' control.

The province of Badajoz experienced the uprising very differently, as it continued to support the Republican government until the beginning of August. After the failed coup, the rebels carried out the conquest of uncon- trolled territories by force. Military operations would determine the evolution of the territories in the province of Badajoz in these months. The rebel column advanced from Seville to Madrid through Extremadura, occupying new territories and implementing the first repressive strategies. These strategies would be linked to the seizure, stabilization and control of these territories in the early stages of the occupation and in the rebels' rearguard (Fig. 1).

With the advance of rebel troops, many of the central and western parts of the province were occupied during the months of August and September of 1936. During the autumn months, the lines demarcating the Extremadura Front were established, and the areas of La Siberia, La Serena and Vegas Altas in Badajoz and the town of Alía in Cáceres remained under Republican control. After Franco's summer offensive in 1938, only La Siberia would remain in Republican hands. It stayed under Republican control until the end of the Civil War in 1939 (Fig. 2).

The different ways in which these distinct territories evolved during the war and their subsequent development is also reflected in the number of victims that fell to Francois repression and in the repressive strategies that the rebels implemented in different areas. According to Martin Bastos (2013) the total number of identified victims of the Francoist repression in the region of Extremadura amounts to 13,205, of which 2,000 died in the province of Cáceres and 11,205 in Badajoz.

In recent decades, numbers of researchers have analyzed the repression suffered by civilians during the Civil War and dictatorship in this region (Chaves, 1995; 1997; 2005; Espinosa, 2003; Gutiérrez, 2003; Martín, 2013; C.

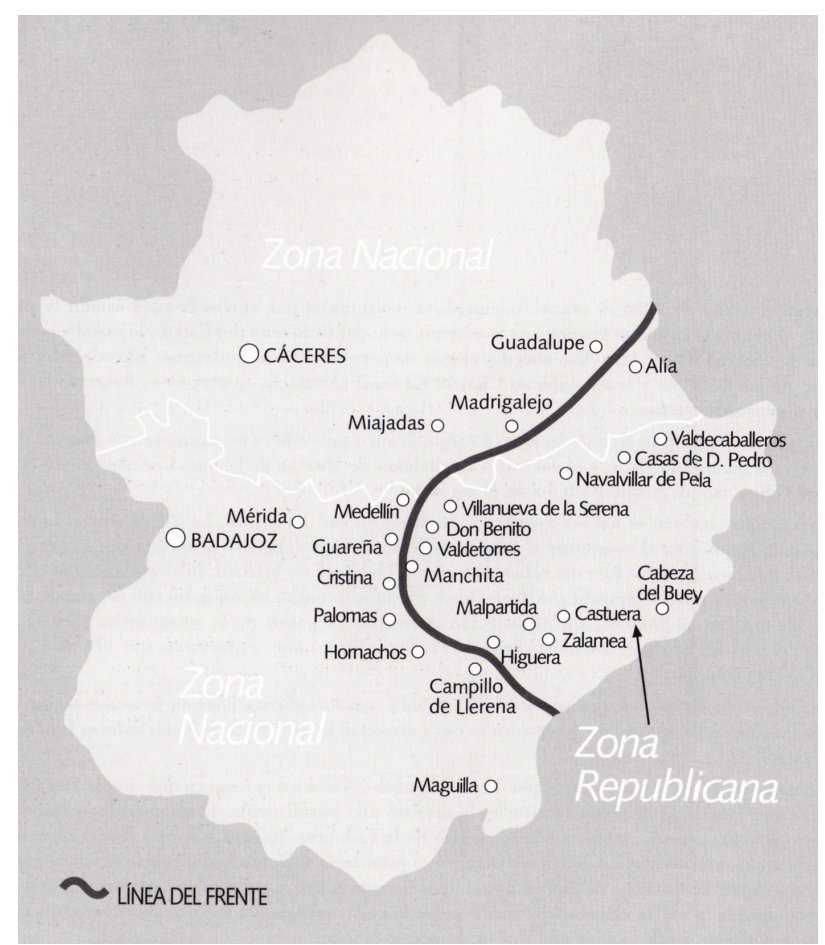

FiguRe 1: Map of the Extremadura Front from October 1936 to July 1938. (Chaves, 1997: 186) 


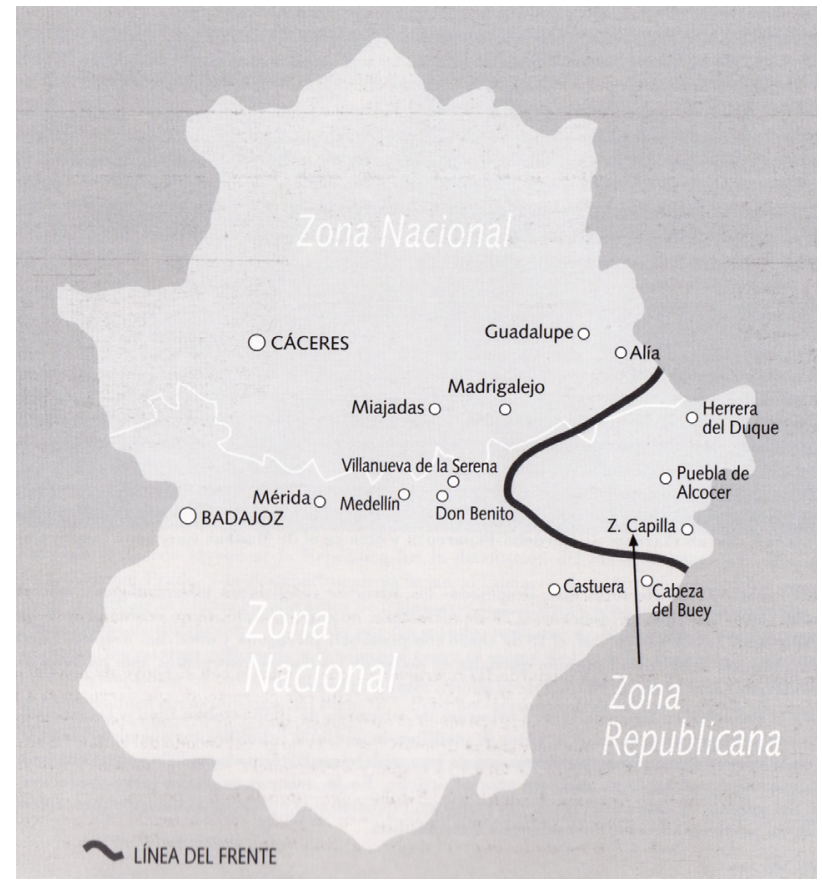

FIgURE 2: Map of the Extremadura Front after the operations deployed to occupy the "Bolsa de La Serena" ("Bag of the Serena) in the summer of 1938 (Chaves, 1997: 231)

Chaves, 2014). As a recently emergent field, studies of the contemporary past have also included the investigation of forms of war and postwar repression in relation to the exhumation of mass graves resulting from the conflict (Muñoz-Encinar and García, 2010a; Muñoz-Encinar and García, 2010b; Muñoz-Encinar and García, 2011; Muñoz-Encinar and Rodríguez-Hidalgo, 2011; Muñoz-Encinar et al., 2013).

During the last decade, many campaigns to locate and exhume mass graves containing the bodies of disappeared individuals have been accomplished across the region of Extremadura (Chaves et al., 2014). Most of these interventions have been performed by the research initiative entitled, "Project for the Recuperation of Historical Memory in Extremadura" based at the University of Extremadura (PREMHEX). This project seeks to investigate Francoist repression during the Civil War and the dictatorship in Extremadura from a multidisciplinary perspective.

\section{EXHUMATIONS OF MASS GRAVES IN EXTREMADURA}

In Extremadura, the exhumation of mass graves resulting from Francoist repression dates back to the early 1970s when, even before the arrival of democracy, victims' families developed and promoted the first exhumation projects. After the death of the dictator, these exhumations took place within a complex climate of political and social tension.

These exhumations had a strong media impact, as reflected in the publication of articles in state magazines that recounted victims' experiences with repression during the dictatorship and that described the social atmosphere in which these bodily recoveries were conducted. ${ }^{2}$ This social and media impact of these publications also reflects the need for acknowledgement and reparation of a society silenced and repressed for nearly four decades during the dictatorship. These exhumations, which happened unconnected to any scientific guidance or expertise, would not lessen until after the coup on February $23^{\text {rd }}, 1981$. However, exhumations continued to be conducted in Extremadura during the 1980s and 1990s.

These exhumations carried out during the first decades of the democratic period sought to recover disappeared bodies and repair the dignity of those who fell victim to Francoism, not only for victims' families but also at a more collective level. In these years, numerous memorials inscribed with the names of all the missing were erected to honor memory of the defeated in different villages.

This first stage of exhumations in Extremadura ends, like similar stages in other parts of Spain, at the turn of the century. In 2000, the first mass grave of Franco's repression was opened through the deployment of scientific methods in Priazanza del Bierzo (Prada et al., 2003). This event marked a paradigm shift and a great quantum leap in the development of exhumations in the Spanish State (Ferrándiz, 2007; 2011). A new phase of exhumations began thereafter, characterized by the search for truth and knowledge about the past and the identification of the victims through the scientific analysis of the recovered mortal remains.

In Extremadura, the exhumations acquired a scientific character following the trend started in Priaranza del Bierzo in 2003. From this moment onwards, exhumations were carried out under specific legislation that controls archaeological activities in the region. Therefore, from a legal point of view, the opening, excavation and exhumation of mass graves is regulated by the General Directorate of Cultural Heritage, which belongs to the Extremadura's Ministry of Education and Culture. The administration ${ }^{3}$ would subsequently control and supervise these actions and the rigorous application of the rules that govern archaeological work in the region. ${ }^{4}$ PREMHEX began working on the study, location and exhumation of mass graves resulting from the Civil War and Francoism in this context.

The search and exhumation of graves belonging to different times and repressive contexts between 1936 and 1946 has been carried out in accordance with the research aims of the abovementioned project. A total of 60 exhumations have been completed, in which the bodies of 380 people (Chaves et al., 2014) have been recovered. This number represents, according to Martin Bastos (2013), $2,8 \%$ of a total of 13,205 victims of repression in the region.

In this sense, the exhumations represent a qualitative leap in relation to the recovery of victims' bodies, the production of knowledge about the past and the study of the Francoist repression in the region. However, from a quan- 
titative point of view these exhumations constitute a very small percentage of the total number of people executed and disappeared during the Civil War and the dictatorship in this particular region. Therefore, the research related to the search and recovery of the bodies of the missing and the location of mass graves is currently an ongoing process, and it cannot be understood as a project that has concluded (Table 1).

The map of mass graves in Extremadura was drawn from the various projects undertaken, and it graphically reflects the different types of interventions that have been carried out (Ibarra, 2009; Ibarra, 2010b; Chaves et al., 2014).

In this map, we include a category that we have termed al alba, corresponding to the graves exhumed during the transition and the decade of the 1980s and 1990s in the region. In addition, this map also contains the category of anticipated mass graves corresponding to mass graves that have been located and that are waiting to be excavated or mass grave localization projects that are at an advanced research stage (Fig. 3).

The main exhumations in Extremadura are shown in Table 2, which contains the year when each exhumation was started, the location of the mass grave and the minimum number of individuals (MNI) exhumed.

Of the nineteen exhumations completed between 2003 and 2013, we have selected five case studies, which correspond to different contexts and chronological moments. Each of the case studies is an example of the different phases and repressive strategies developed in Extremadura between the moment of the uprising in July 1936 to the occupation of territories by the rebel troops and the early years of the Franco regime in the region.

The paper, then, presents one case associated with the occupation of territories and with the military rebel

TABLE 1. Project conducted by Premhex (Chaves et al., 2014)

\begin{tabular}{|c|c|c|}
\hline \multicolumn{3}{|c|}{ PROJECT CONDUCTED BY PREMHEX } \\
\hline Year & Exhumation & Research/Prospecting \\
\hline 2003 & 1 & 0 \\
\hline 2004 & 0 & 9 \\
\hline 2005 & 2 & 0 \\
\hline 2006 & 0 & 2 \\
\hline 2007 & 3 & 4 \\
\hline 2008 & 1 & 5 \\
\hline 2009 & 6 & 5 \\
\hline 2010 & 1 & 3 \\
\hline 2011 & 4 & 6 \\
\hline 2012 & 3 & 2 \\
\hline 2013 & 1 & 2 \\
\hline Total & $\mathbf{2 2}$ & $\mathbf{3 8}$ \\
\hline \multicolumn{2}{|c|}{} \\
\hline
\end{tabular}

TABLE 2. Exhumations in Extremadura between 2003-2013 (Chaves et al., 2014)

\begin{tabular}{|c|c|c|}
\hline Year & Location & NMI \\
\hline 2003 & Mina de Valdihuelo & 15 \\
\hline 2005 & Calamonte & 3 \\
\hline 2005 & Llerena & 35 \\
\hline 2007 & Pozuelo de Zarzón & 6 \\
\hline 2007 & Salvatierra de los Barros & 4 \\
\hline 2007 & Villar del Rey & 2 \\
\hline 2008 & Mérida & $150^{1}$ \\
\hline 2009 & Escurial & 16 \\
\hline 2009 & Escurial II & 1 \\
\hline 2009 & Villasbuenas de Gata & 6 \\
\hline 2010 & Mirandilla & 1 \\
\hline 2011 & Santa Amalia & 8 \\
\hline 2011 & Castuera & 36 \\
\hline 2011 & Cabeza la Vaca & 4 \\
\hline 2011 & Quintana de la Serena & 4 \\
\hline 2011 & Arroyo San Serván & 3 \\
\hline 2012 & Puebla de Alcocer & 42 \\
\hline 2012 & Fregenal de la Sierra & 43 \\
\hline 2013 & Cuacos de Yuste & 1 \\
\hline \multicolumn{2}{|r|}{ Total } & 380 \\
\hline
\end{tabular}

${ }^{1}$ The number of individuals exhumed in the graves of Mérida is estimated in relation to the dimensions of the deposit and the isolated bones found in archaeological excavation.

troops' occupation of a town located in a strategic area of the province of Badajoz. It also analyzes two cases of rearguard executions, carried out in areas controlled by the Francoist army since the first months of the uprising. Additionally, we describe a fourth case that is chronologically after the end of the war and associated with the establishment of concentration camps and prisons. Finally, the paper will examine a case of repression against antiFranco guerrilla activity.

\section{The repression associated with the military occupation: The graves of the Romanzal Stream in Llerena (Badajoz)}

Llerena is located in the southeast section of the province of Badajoz, very close to the province of Seville. Due to its strategic location, Llerena was a clear objective for Franco's troops (Espinosa, 2003: 12) due to its proximity to the main highway, formerly known as the N-630 Highway, that cross the region in a north-south direction. It was through this path that troops advanced to Madrid. Its location was also important because it linked the province with the province of Córdoba. 


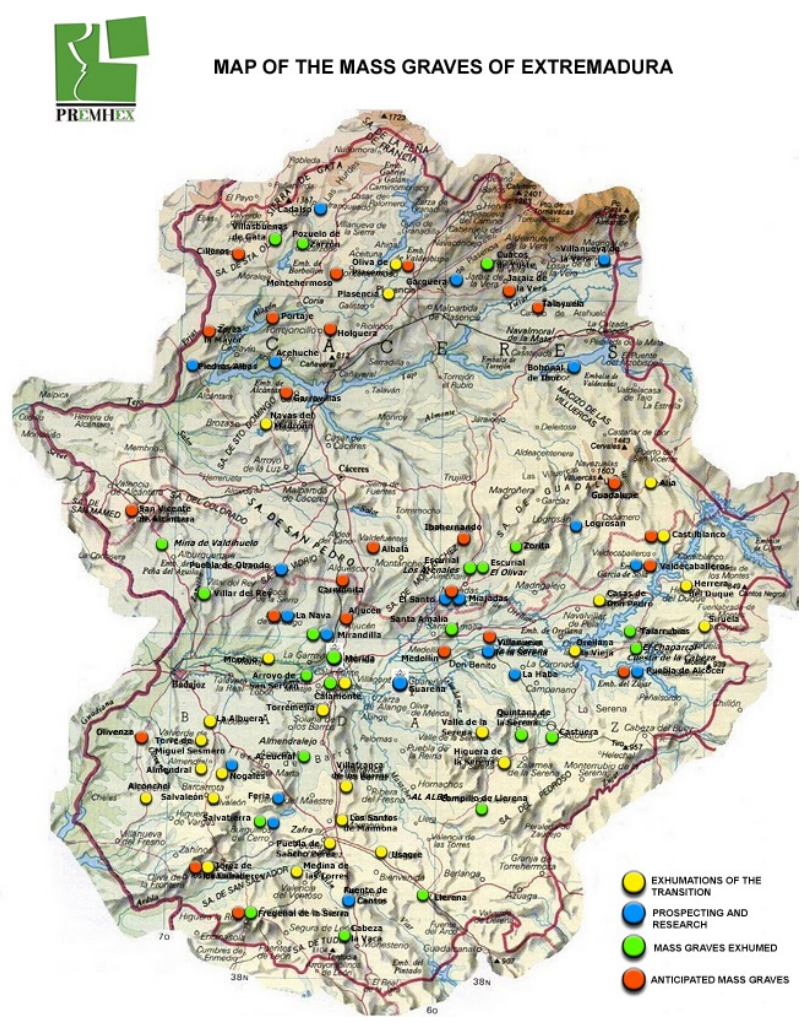

Figure 3: Map of the Mass Graves of Extremadura (Chaves et al., 2014)

During the occupation of Badajoz by the Francoist army, the column of Major Castejón, ${ }^{5}$ which had split from the main column under the command of Lieutenant Colonel Carlos Asensio Cabanillas, would be responsible for taking Llerena (Espinosa, 2003:13) - a village with a resilient and consolidated working class movement (Olmedo, 2010: 51). Its occupation, on August $5^{\text {th }}$, 1936 was especially violent. Castejón encountered strong opposition in Llerena, which his army fought fiercely by burning many parts of the city and attacking the two main points where the resistance concentrated: the village town hall and the church (Espinosa, 2003: 13). As a result, approximately two hundred deaths were recorded in the first days of the occupation (Espinosa, 2003: 282). Later on, on August $31^{\text {st }}$, the Republicans tried to reclaim the city. Although they failed to recover all of Llerena, they managed to temporarily occupy several neighborhoods, thereby destabilizing the front lines (Espinosa, 2003: 15-16). In the following days, the rebels proceeded to arrest a large number of people in Llerena. Generally, the walls of the cemetery were chosen as the sites where executions would be carried out. Nonetheless due to the instability of the front and its proximity to the cemetery, executions were also carried out next to the Romanzal Stream between September $7^{\text {th }}$ and $8^{\text {th }}, 1936$ (Muñoz-Encinar and García, 2010b: 57).

Many victims' relatives and neighbors living in Llerena knew the exact location of the graves of Romanzal. Following their testimonies and the information obtained from different archival documents, these two graves were located and exhumed in the summer of 2005 (Muñoz-Encinar and García, 2010b: 57; 2011).

The Romanzal Stream, where the graves were located, is in an area near the town of Llerena and few meters from the EX-103 road. Therefore, even though the mass graves were located very near the bank of the stream, following the geography of the terrain, the enclave was highly visible from the main road and its surrounding areas.

In Mass Grave I, we exhumed a minimum nineteen individuals of both sexes and of different ages (MuñozEncinar and García, 2010b: 59). After the individuals located in this grave were thrown into the deposit, they underwent a process of cremation leaving the bodies unburied for days. The distribution and orientation of the bodies and limbs shows a random arrangement of the corpses (Muñoz-Encinar and García, 2010b: 125). From the location of the mass grave and the disposition and accumulation of the dead bodies inside of it, we can infer the fortuitous character and the lack of planning of the executions.

With regard to the weapons employed, ammunition belonging to 7.57 caliber Mauser rifles (caps and bullets) was documented. This ammunition was commonly used by the rebel army. It was found together with fragments of a comb, a fuse and other pieces of weaponry (Fig. 4; Fig. 5).

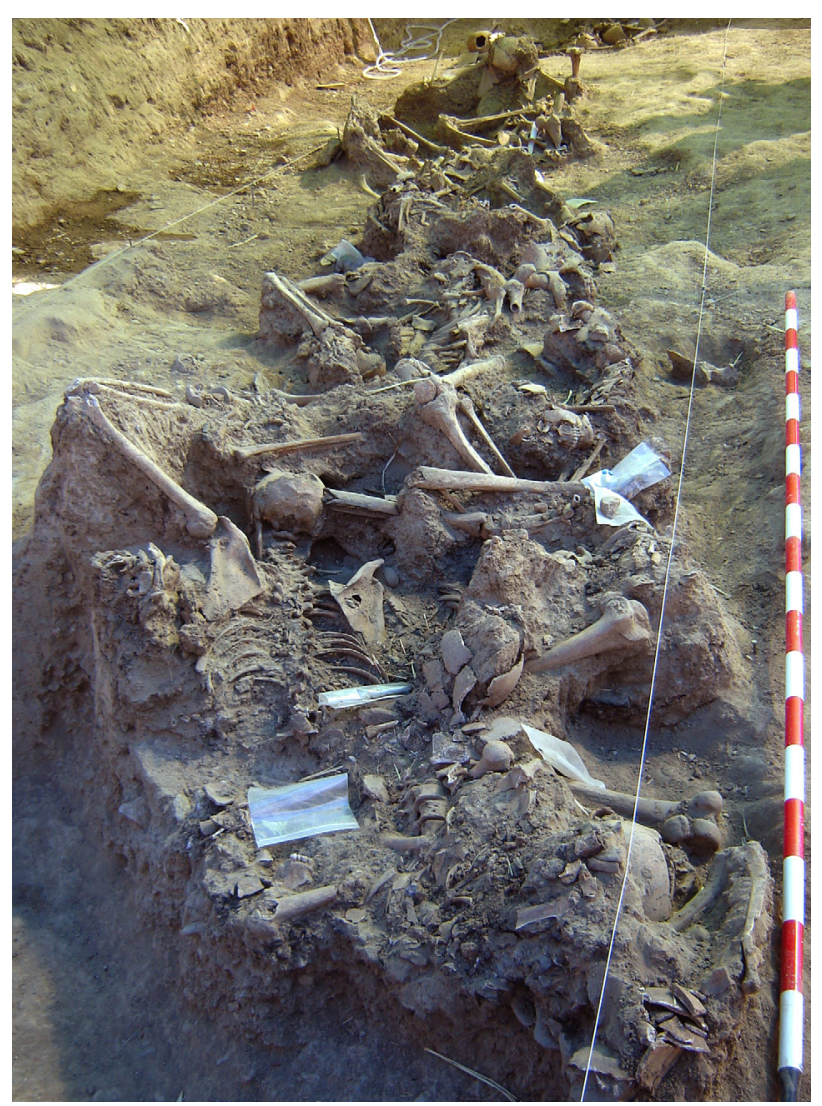

FiguRE 4: Mass Grave I of the Romazal Stream where a minimum number of 19 individuals was exhumed (Muñoz-Encinar, García, 2010a:105) 


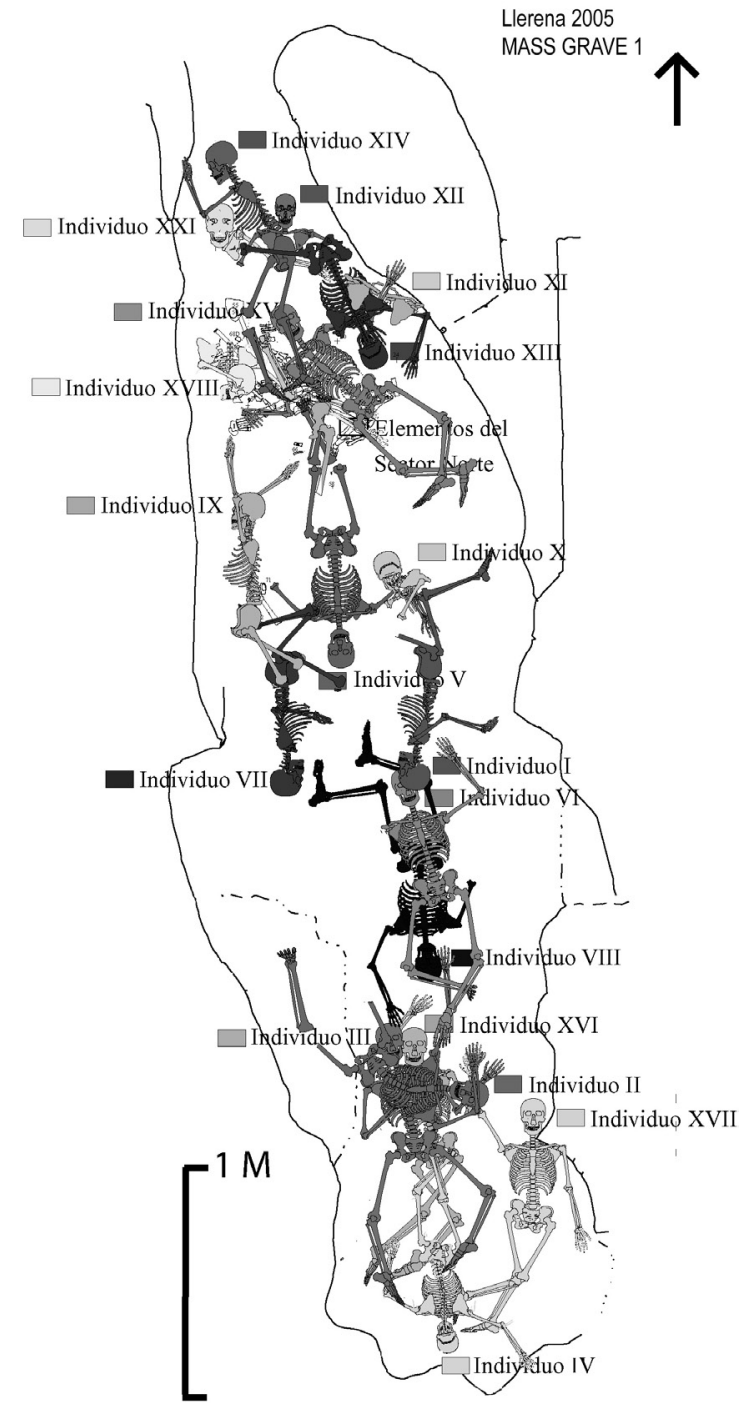

FIGURE 5: Drawing with the distribution of bodies inside of Mass Grave I - Romazal Stream (Muñoz-Encinar, García, 2010a:107)

The second mass grave, located barely a meter away from the previous burial, contained a total of sixteen individuals of both sexes and various ages (Muñoz-Encinar and García, 2010b:59). The disposition of bodies observed in this mass grave varied greatly with respect to Mass Grave I. In this deposit, we observed an organized disposal of remains and a rational use of the space. In this case, all the bodies showed the same orientation and limb arrangement, which was adapted to the deposit in a standardized manner (Muñoz-Encinar and García, 2010b:59). Furthermore, no traces of weapons or ammunition were found. On this occasion, the absence of ammunition may be due to multiple factors. It is possible that the executions were carried out near the mass grave (though not in the deposit) or that the bodies were moved from another location to be buried in the Romanzal Stream.

After first using the Romanzal area for burying the corpses found in Mass Grave I, the second mass grave indicates the planning and carrying out of executions in the days that would follow, due to having acquired a better understanding of the area. Mass Grave II shows an organized and standardized pattern in relation to the morphology of the deposit and the management of dead bodies in the grave (Fig. 6; Fig. 7).

The objects and personal belongings found in both mass graves are associated with groups of civilians. The significant presence of valuable items (rings, cufflinks, medals and coins) suggests that the detainees were not searched (Muñoz-Encinar and García, 2010b:61-64).

\section{Areas that supported the uprising: The repressive practices of paseos and the places of terror}

\section{Los Paseos: Villasbuenas de Gata (Cáceres)}

Villasbuenas de Gata is a small town located in the north of the province of Cáceres near the border with the province of Salamanca. This area, like other areas in Cáceres, manifested its support to the rebels in the early days of the military uprising. After the dissolution of the town halls and other legitimate organizations associated with the Second Republic, falangistas and the Civil Guard controlled these localities and occupied territories and arrested all those neighbors of the town who had links to the Popular Front (Chaves, 1995: 128). The re-

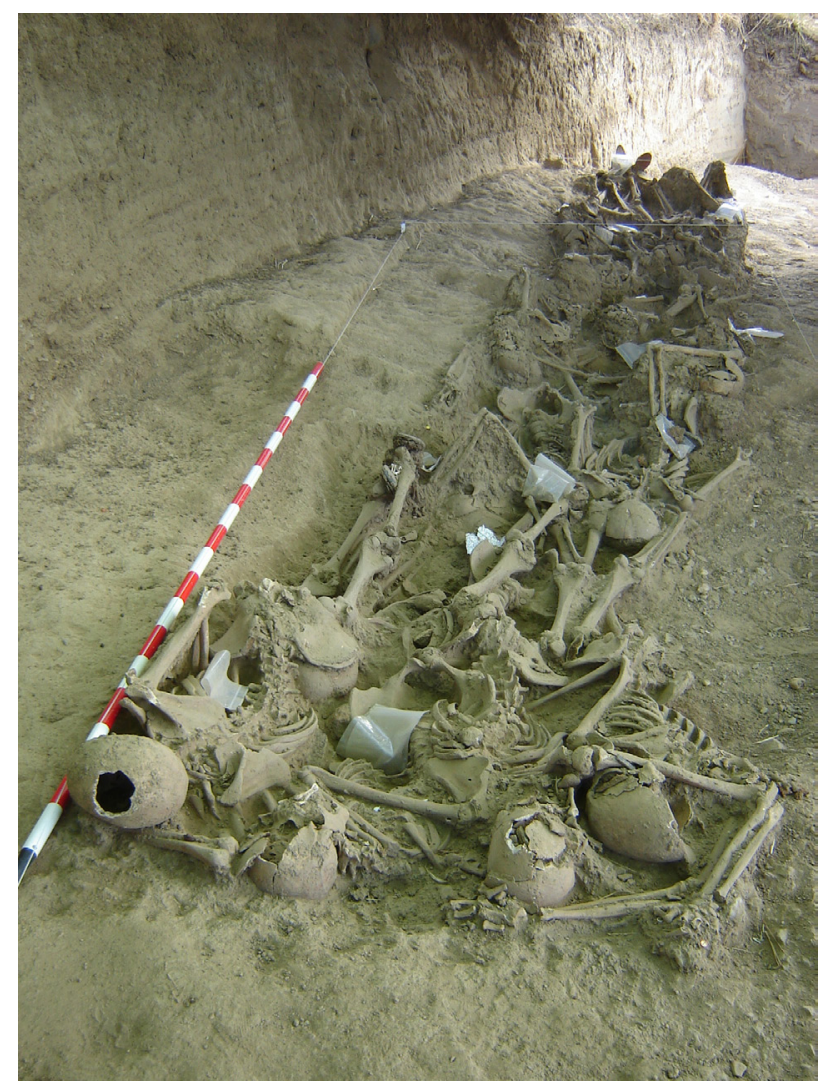

FIGURE 6: Mass Grave II- Romazal Stream where 16 individuals were exhumed (Muñoz-Encinar, García, 2010a:106) 
pressive practices developed in these areas are known as paseos or sacas. These practices usually entailed the arrest and execution of a particular selection of individuals or group of civilians who were involved in some kind of political activity or showed any sympathy for the Republic.

The research conducted in Villasbuenas de Gata prior to the excavation showed that there were several mass graves located in different locations in the municipality (Chaves, 1995:128; Ibarra, 2012). In Villasbuenas, four men from the village were executed together with other people who came from neighboring towns (Chaves, 1995:128; Ibarra, 2012: 135). All of them were impris-

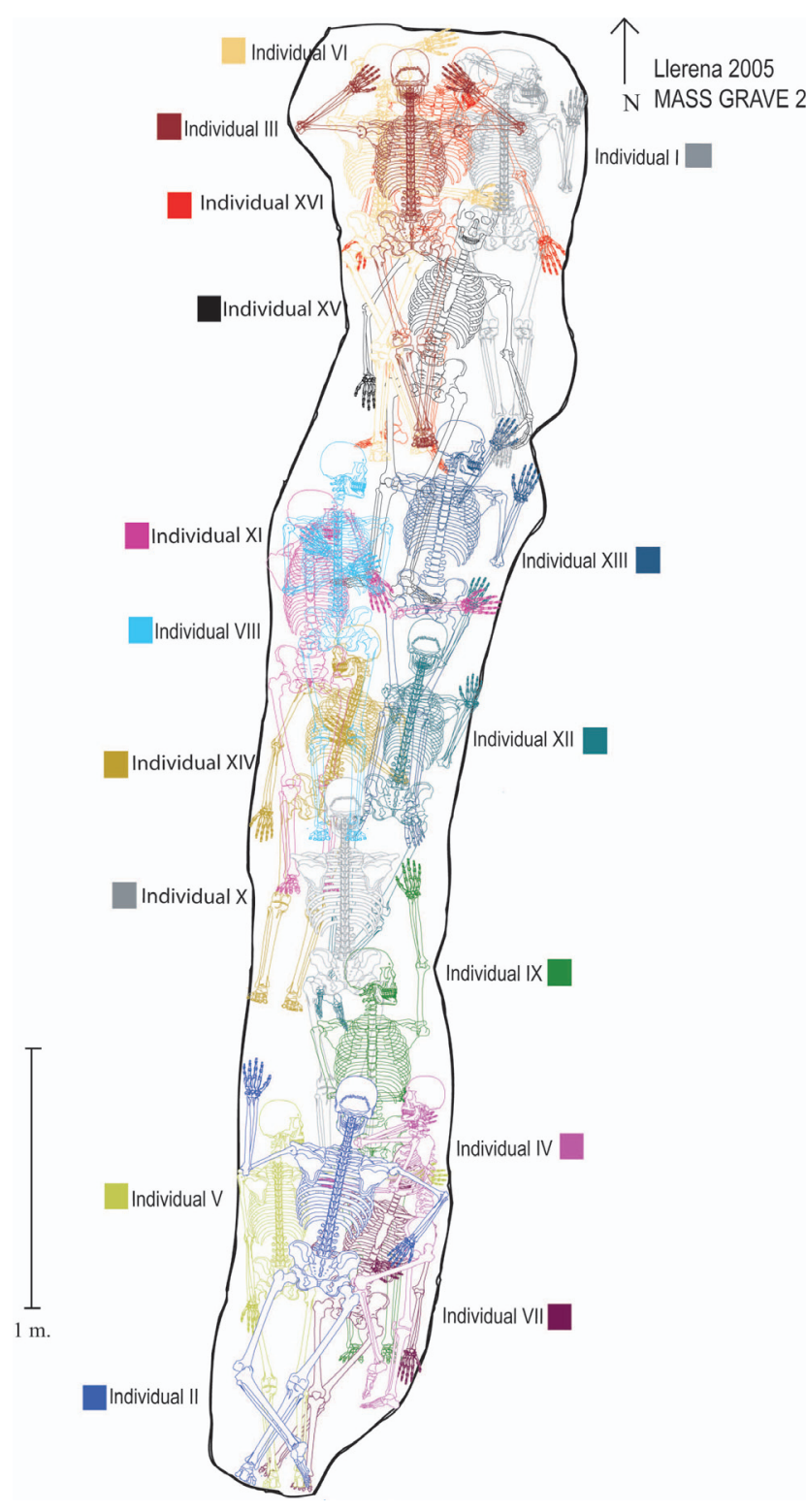

Figure 7: Drawing with the distribution of bodies inside the Mass Grave II - Romazal Stream (Muñoz-Encinar, García, 2010a: 114) oned and later executed in several areas located on the side of the roads that led to the municipality.

In one of these areas, called Los Romeros, we documentated the location of two graves where two men were buried in supine position, with their the lower limbs stretched and their uppers limbs slightly bent over the body. Individual 1 in Grave 1 bore various items of clothing, including black rubber shoes. A pin with the inscription "Dumlop" was documented among his personal belongings. Individual 2 in Grave 2 wore leather boots, several buttons and carried no personal belongings. Bullet casings from a $9 \mathrm{~mm}$ pistol were found in both bodies. These were the weapons generally used by the Civil Guard and paramilitary groups such as Falange. The bullets were found in the individuals' skulls and in different postcranial parts. They are associated with their cause of death (Fig. 8; Fig. 9).

The two people buried in these mass graves were José Prieto Martín and Eduardo Gutierrez Roncero, neighbors of the village of Robleda (Salamanca). They were arrested, taken from their homes and driven to Villasbuenas, where they were imprisoned for several days. A few days later (the nights of September $28^{\text {th }}$ and $29^{\text {th }}, 1936$ ), the

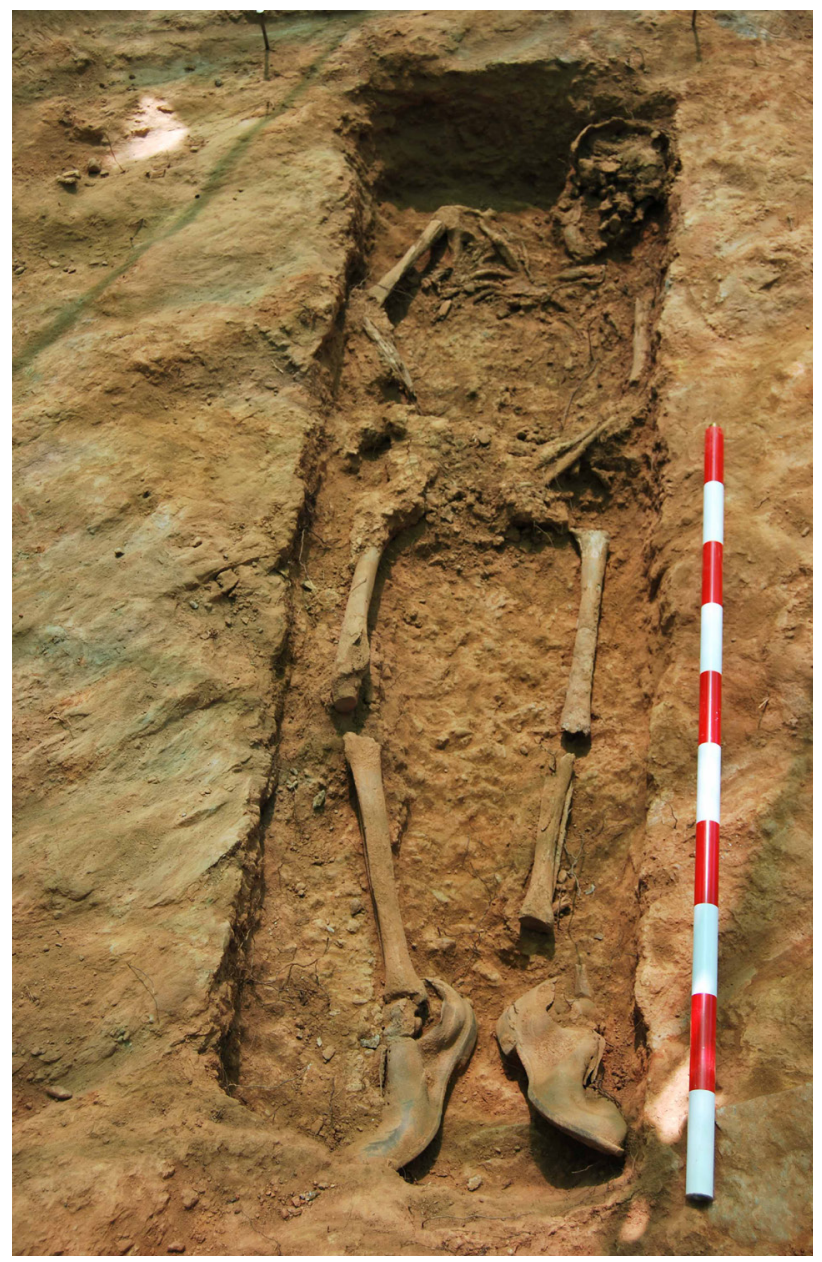

FIGURE 8: Grave 1 located in the ditch at the site of Los Romeros (Villasbuenas de Gata) 


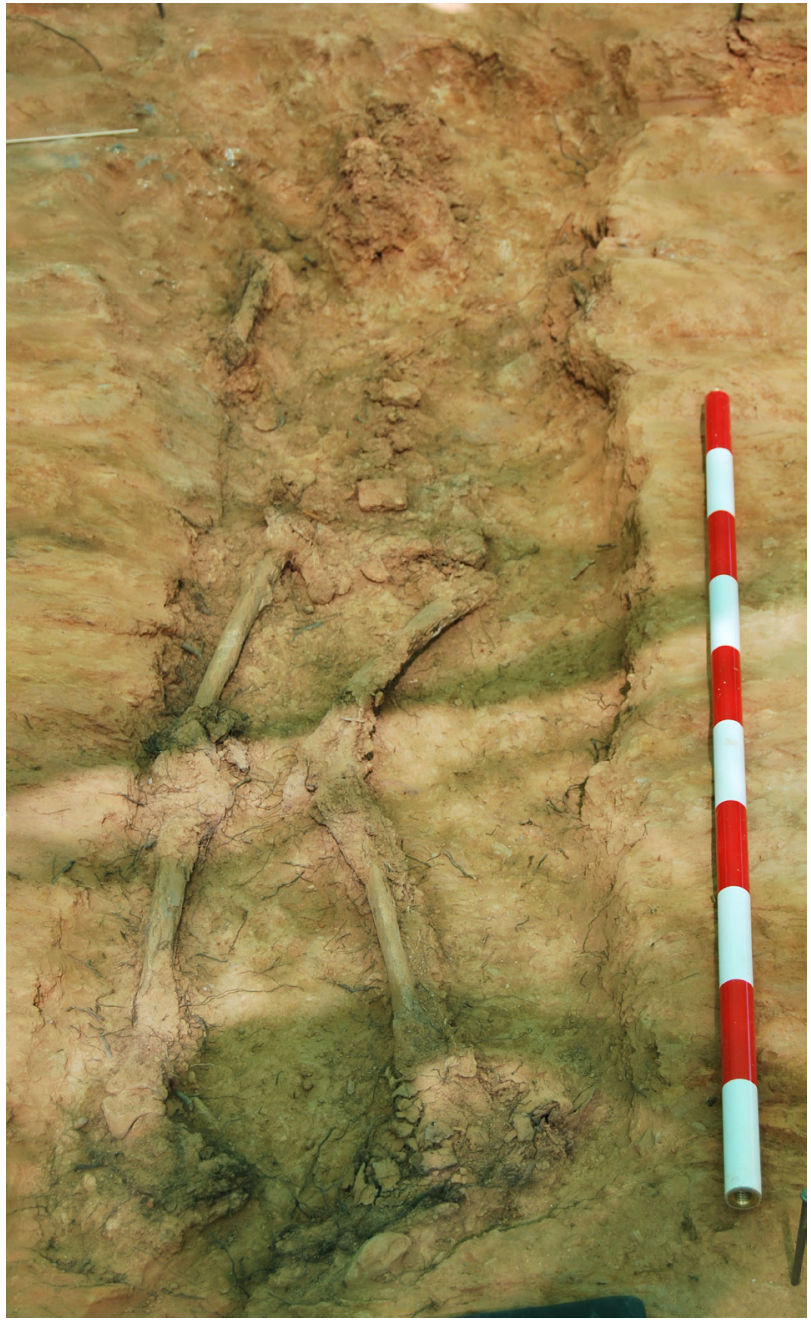

FIGURE 9: Grave 2 located in the ditch at the site of Los Romeros (Villasbuenas de Gata)

two men were released from jail, executed and buried in a ditch of an area known as Los Romeros. They were located and exhumed in 2009 (Muñoz-Encinar, 2010).

\section{The Places of Terror: Los Arenales, Escurial (Cáceres).}

Escurial and the surrounding villages are in an area where the support of the coup of July $17^{\text {th }}, 1936$ was almost immediate. In spite of this, a large number of neighbors from all areas of the region were executed during the months of August and September, 1936. These people were mainly those who had shown some support to the legitimate regime of the Republic. In Escurial, arrests and executions, mainly carried out through paseos by Falange, started on August 2 ${ }^{\text {nd }}$ (Chaves, 1995: 160). These executions were realized in the town or outside the cemeteries of the nearby villages. There was also an area next to the village where executions were systematically carried out during the Civil War, mainly in the summer months of 1936.

Neighbors from Escurial and nearby towns (Miajadas, Santa Amalia, Almoharín, Villamesías, etc.) remembered the existence of multiple mass graves in an enclave known as Los Arenales (Chaves, 1995:161). This enclave operated between 1936 and 1939 as a place of terror, becoming a recurring area for hiding victims' bodies. Trucks containing civilians that had been arrested in the surrounding villages were driven to this area. The civilians were later executed and buried in mass graves in this same spot (Chaves, 1995: 162-163; Muñoz-Encinar and Rodríguez-Hidalgo, 2010).

\begin{abstract}
The outskirts of Escurial and the area of Los Arenales became a real cemetery, even if there was no cemetery located there, because many executions were carried out in that place. At nighttime, in August and September of 1936, we could hear the shooting and the groaning of the executed that were still alive from the village. The person responsible for burying the bodies would finish them off the next morning. (Testimony of Delfa Jiménez in Chaves, 1995:161)
\end{abstract}

Based on this information, we began a project that sought to locate the mass graves and exhumation the bodies buried in this place of terror in Escurial. Through the archaeological excavation of the area, two mass graves were found in very close proximity. Unfortunately, farming in the area, the unification of plots and the modificaton of the land due to the introduction of irrigation channels changed the landscape drastically and prevented the localization of the other mass graves identified through oral testimonies.

The mass graves were located on the edge of a stream that marked a change in the terrain, creating an area that was topographically lower than the rest. This facilitated the task of burying the bodies and concealing the mass graves (Muñoz-Encinar and Rodríguez-Hidalgo, 2010: 272). Due to the sedimentary context, the conservation of the remains was deficient and many anatomical parts were missing.

Both deposits have a very similar morphology, especially regarding orientation and size. In Mass Grave I a minimum number of seven individuals were recovered. In Mass Grave II we documented a total of nine individuals, six male and three female, all of them of adults (Muñoz-Encinar and Rodríguez-Hidalgo, 2010: 273).

In both mass graves, the bodies had different orientations following an order inside the deposit with a standardized pattern. The internal organization of the mortal remains follows the parameters of an orderly and intentional burial (Muñoz-Encinar and Rodríguez-Hidalgo, 2010: 277).

In Mass Grave II, we observed a differential order of the individuals in relation to their gender. Males were deposited in the central and eastern sides of the grave and arranged longitudinally with their heads facing east. Conversely, females were placed on the west side of the grave and arranged longitudinally and obliquely to the axis of the deposit, with their heads facing west (Muñoz-Encinar and Rodríguez-Hidalgo, 2010:277-278). By analyzing the sequence of the corpses, we observed that these three female individuals were the last to be introduced into the grave.

The differences in the general pattern of the corpses' disposition and their ordering in relation to their gender can be interpreted as a way of differentiating the group of 
detainees on the part the firing squad. This differentiation could be associated with perimortem practices used to degrade the victims (Fig. 10).

We came to the conclusion that heavy perimortem violence was linked to the cause of death (from the presence of bullet holes in the skull and postcranium) and linked to the direct violence exerted through the repressive techniques used by the perpetrators. This violence was inferred from the identification of perimortem trauma and fractures on different parts of the bodies exhumed (Muñoz-Encinar and Rodríguez-Hidalgo, 2010: 276).

The objects associated with the bodies in each case belonged to civilians. Abundant items related to clothing (buttons, buckles, soles, zippers, etc.) and many personal belongings were also found. Among the personal items, the presence of valuables such as earrings, a gold ring and coins demonstrated that the victims were not searched. This data can indicate that these people did not undergo a lengthy process of detention. It is usually at this stage of the proceedings when detainees would have been registered and stripped of their most valuable belongings.

In both contexts remnants of ammunition, bullets casings and bullets were documented. All bullet casings belonged to the same type of weapon, Mauser rifles, the mandatory weaponry of the rebel army. The presence of this type of ammunition in the context of the mass graves indicates that the executions took place near the deposits (Muñoz-Encinar and Rodríguez-Hidalgo, 2010:279) (Fig. 11; Fig.12).

\section{Repressive contexts after the end of the Civil War: Castuera (Badajoz)}

\section{The establishment of Prisons and Concentration Camps}

Castuera is located in the eastern part of the province of Badajoz in the area of La Serena. After the military uprising, it remained an strategic center in the Republican area of the province, becoming its capital until its fall on July $23^{\text {rd }}, 1938$. The rebels' takeover of Castuera was part of the offensive carried out in the Extremadura front early 1938 with the aim of ending the so-called Bolsa de la Serena (The Bag of the Serena). This offensive ended in July 1938 with the closing of La Bolsa and the loss of much of the territory that comprised the Republican zone in Extremadura. As a result, the front of Extremadura would be drastically reduced, finally collapsing in March of 1939 with the end of the Civil War.

The municipal cemetery of Castuera became incredibly relevant during the fascist occupation of the city, an observation that have inferred due to the fact that most of the mass graves of people executed during 1938 are located there. From an analytical perspective regarding Francoist repression, the northern part of the cemetery becomes the most important area to study. It is located concretely near the main entrance where, according to oral testimonies, mass graves from the first repressive campaigns were located. This repressive phase expands
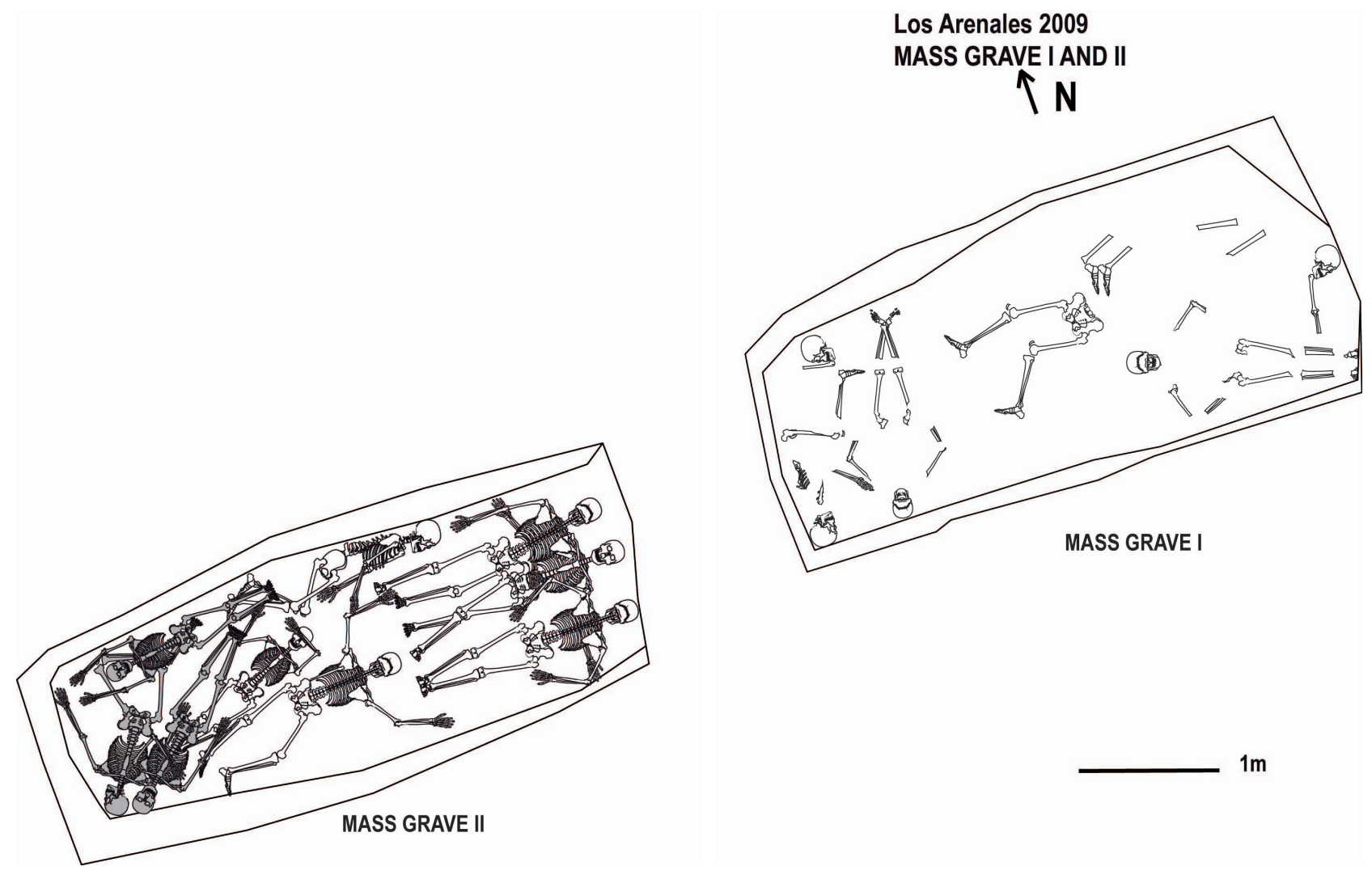

FIGURE 10: Drawing of the mass graves of Los Arenales (Escurial), the female individuals correspond to the gray color 
from the moment of the town's occupation to the end of the war.

The next repressive phase starts after the war ends with the establishment of the concentration camp of Castuera (López, 2006; 2009). This moment is also characterized by the use of other spaces, such as the rear part of the cemetery, to conceal victims' bodies.

Numerous testimonies identified the rear of the cementry as an area where multiple mass graves existed as a

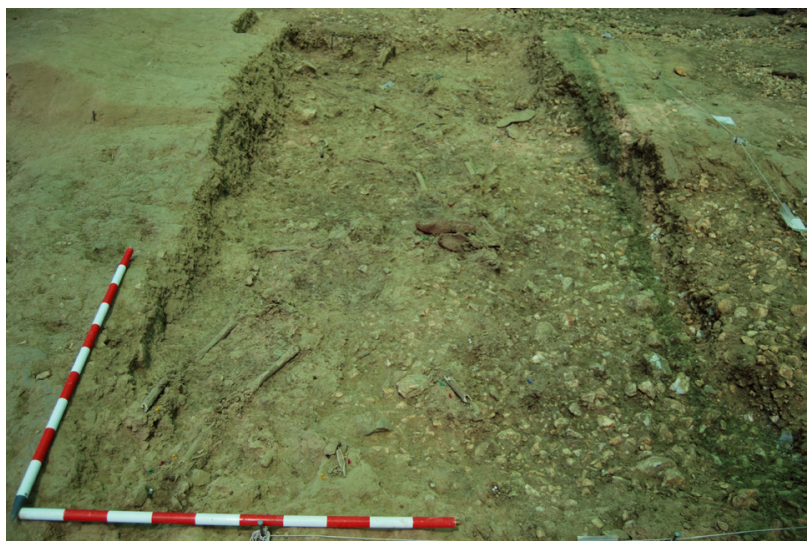

Figure 11: Mass Grave I of Los Arenales

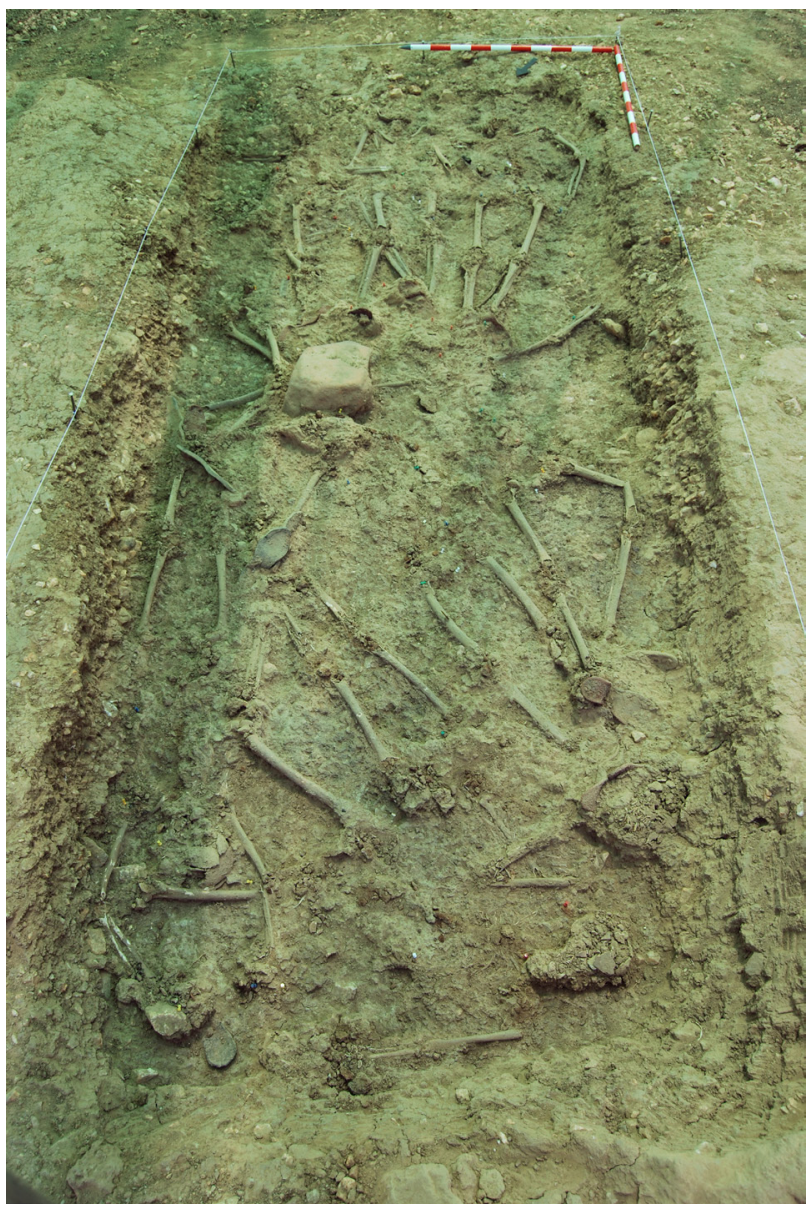

Figure 12: Mass Grave II of Los Arenales result of the Franco regime's repressive tactics. These burials were carried out at different moments during the dictatorship. Most significantly, our informants insisted on the existence of numerous mass graves related to the concentration camp and the prison linked to Judicial District of this area. Moreover, the same sources indicated there were numerous mass graves that hinted at similar repressive acts in other areas outside the cemetery, such as the mines close to the concentration camp and other nearby places. The use of different places for the concealment of corpses is connected to the chronological moment in which the disappearances occured. In addition to this, we can elucidate a differentiated use of such spaces in relation to the repressive process employed, which is simultaneously related to other locales and the coercive materiality of the Franco regime.

A couple of Civil Guard [of falangist adscription] went barrack after barrack calling names, with some papers in hand. Then, the following night, they came to get the people... Those who fired the shots were falangistas. The people were executed in the cemetery of Castuera. Somebody dug trenches during the day [in the cemetery]. We saw the ditches on our way to fix some roads leading to Castuera. The following day, when we went back to fix some other things, we saw that a large part [of the trench] had already been covered.

Testimony of Zacarías Jiménez Murillo (in González 2006b: 458).

We located several mass graves belonging to different chronological moments after the end of the Civil War in the municipal cemetery of Castuera.

Mass Grave 1, located in the southern part of the cemetery, showed a northwest-southeast orientation. The mass grave had a length of $11.25 \mathrm{~m}$ and a width varying between $1 \mathrm{~m}$ and $60 \mathrm{~cm}$. Its south side was $10 \mathrm{~cm}$ deep and its north side was $50 \mathrm{~cm}$ deep. The remains of twenty two individuals in anatomical position were identified in this mass grave. Various objects associated with the cadavers were also recovered (Fig. 13).

All bodies were placed along the longest axis of the deposit with their heads facing south and southwest, except for one individual who was found in a transverse position with his head facing northwest. The bodies were found in pairs in one level of burials. All individuals were tied in pairs by one of their arms at the height of the humerus and wrist. In one case, we documented two individuals tied by their wrists and also around their necks, what would impede their mobility almost entirely. This procedure demonstrated that the group of detainees had very limited mobility and were arranged in groups of two people. The placement of the bodies and the positions of the extremities followed a general pattern, which adapted to the morphology of the deposit, showing that the bodies were placed in an organized manner and not thrown inside the mass grave.

According to anthropological data, all persons found in Mass Grave 1 were adult men. Furthermore, we documented that heavy perimortem violence was exerted on 


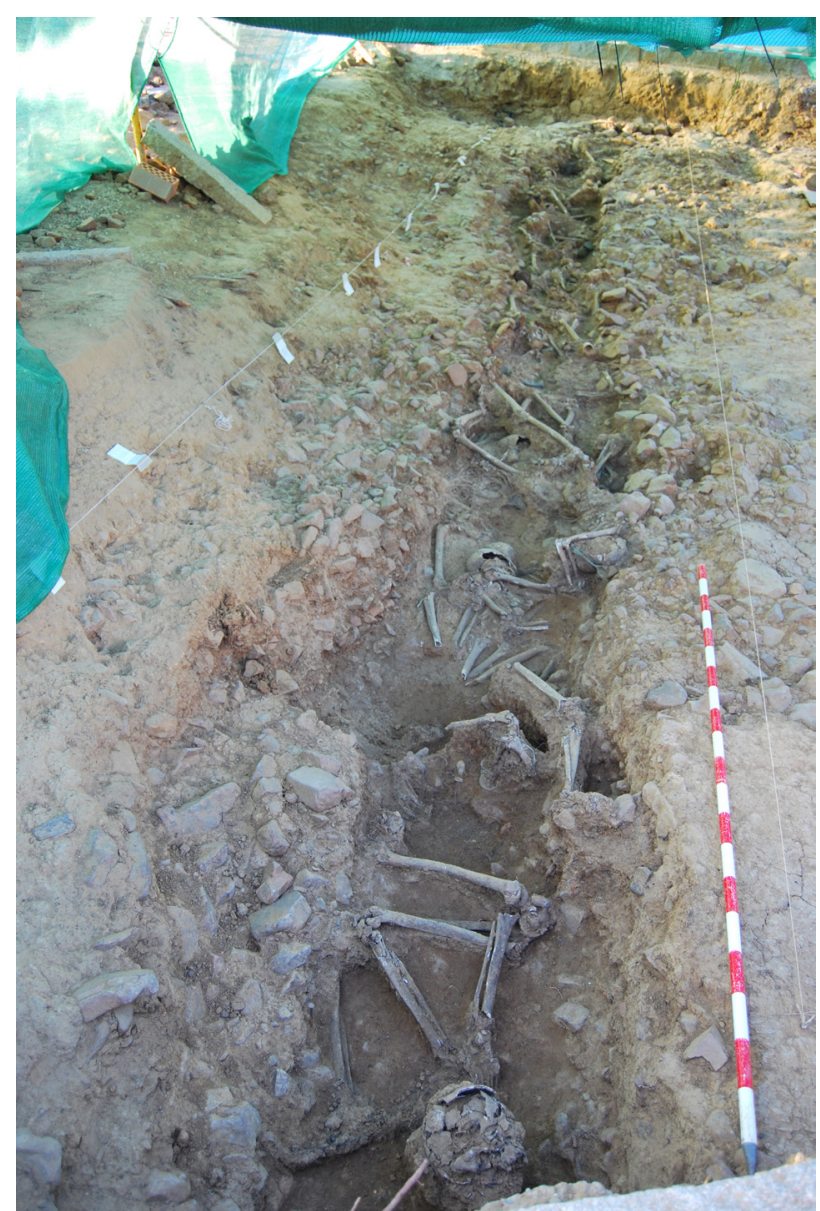

FIgURE 13: Mass Grave 1 of the Castuera Cemetery

the bodies. There were bullet holes in the skulls and postcranial skeletons, and it was determined that these were associated with the cause of death (Muñoz-Encinar et al., 2013:63) (Fig. 14).

A great variety of items were recovered from inside of the mass grave. We found individuals with objects related to uniforms or military-type clothing such as leggings, large belt buckles, straps, etc. We also found other indi- viduals who were wearing civilian attire (Muñoz-Encinar et al., 2013:91-93).

The elements that we call personal effects include a wide range of objects. For instance, two individuals were found with storage items, like a backpack and a bag. The backpack belonged to a member of the Republican Army health unit and the bag probably belonged to the railway station chief (Muñoz-Encinar et al., 2013:95). Both carried many objects related to their professional activity.

We found numerous items associated with food and consumption, such as spoons, can openers and a flask, similar to those items documented in a previous excavation of the concentration camp (González-Ruibal et al., 2010; Muñoz-Encinar et al., 2013:98-99). Other items associated with personal care, such as mirrors, combs and lice combs (Muñoz-Encinar et al., 2013:95-96) were also recovered. We also found items related to the act of writing, all of which allow us to better understand the context of the concentration camp and the daily lives of prisoners (Muñoz-Encinar et al., 2013:101-102). Moreover, other items located in Mass Grave 1 that might not seem very valuable - such as coins, rings, cufflinks and lighters suggest that these people were not searched.

With regard to the objects related to the repressive acts themselves, we found numerous bullets and shells, all from handguns with different calibers. Within this category, we also located the wires used to immobilize prisoners and a fractured glass bottle of wine Pedro Domecq Jerez with a cork cap. From the position and dispersion of the broken glass we can infer that the bottle was thrown violently into the mass grave. The bottle broke into pieces as it hit the ground once the bodies were already in the deposit. The bottle, originally of Jerez wine, had probably been refilled with a different type of drink, as the cork cap found on the top showed. We can therefore deduce that perpetrators consumed alcohol during executions. This indicated that the perpetrators could have been in a state of inebriation (Muñoz-Encinar et al., 2013:108) at the moment when executions took place.

Through the analysis of these objects we believe that executions were carried out in the same area of the cemetery and at a short distance from the mass grave. We can

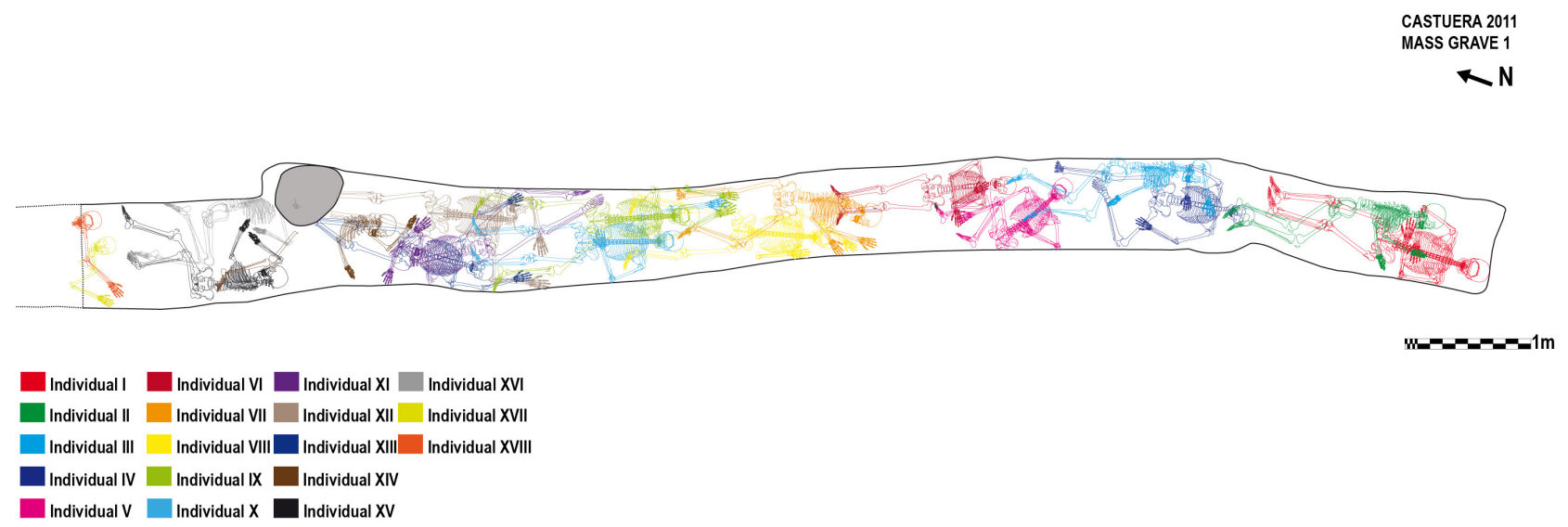

Figure 14: Drawing of the Mass Grave 1 of the Castuera Cemetery 
infer that executions implied some planning on the basis of the treatment of the bodies and their arrangement in the deposit (Muñoz-Encinar et al., 2013: 108; 106). The analysis of all of this data has led us to the conclusion that the group of people buried in Mass Grave 1 was a group of prisoners from the concentration camp. According to the diversity of profiles documented in the mass grave, we think that this group came from the confinement barracks inside the concentration camp (Muñoz-Encinar et al., 2013: 107). This interpretation is consistent with the oral testimonies gathered.

Furthermore, we believe that in Mass Grave 1 we found one of the largest sacas from the concentration camp (López, 2009: 246-247), in this case, probably carried out by a Falange group - a common procedure which has been documented by some authors (González, 2006: 458; López, 2009: 241-52). These people carried all their personal belongings with them, so it is very possible they thought that they were going to be moved to another prison. They were executed once they arrived to the rear of the cemetery, on the road from the camp to Castuera.

\section{The Fight Against the Armed Guerrilla during the Dictatorship}

In the same area of the cemetery, we located another deposit identified as Mass Grave 3. The length of the mass grave was $11 \mathrm{~m}$ and its width varied between $1.10 \mathrm{~m}$ and $55 \mathrm{~cm}$. This trench, oriented to the northwest and southeast, was a deposit used for different purposes, where we found three victims linked to Francoist repression among ordinary burials in coffins connected to the everyday use of the cemetery.

In Mass Grave 3, we documented three individual victims linked to Francoist repression, whose bodies were placed north to south with their heads facing north. The three individuals were adult men who suffered strong violence around the time of death, as the multiple perimortem fractures identified demonstrated. We also documented $9 \mathrm{~mm}$ caliber bullets located in the head and thorax of two individuals and perimortem fractures in their skulls caused by the bullet holes associated with the cause of death (Muñoz-Encinar et al., 2013: 110-112).

In relation to the objects found, the items documented were scarce in this case. Individual I had several objects related to clothing, several buttons, a buckle and a piece of fabric with a coin. Individual II had several buttons, and Individual III had a comb, a button and a metal hook related to piece of clothing.

We believe that Mass Grave 3 corresponds to an area of the cemetery called De los Desamparados, where many dead people were buried in the town during the Franco regime. This type of mass grave shows the existence of mixed deposits, where the deceased townspeople lacking economic resources were buried with the victims of Francoist repression in the same trench over a period of time (Muñoz-Encinar et al., 2013: 113).

In relation to the remains documented in Mass Grave 3 , the three individuals buried were victims of Francoist repression. In addition to this, according to the information published by López (2013), several irregular burials referred to as unknown and described as death due to a sustained struggle with the Civil Guard are recorded in the Castuera's cemetery logbooks on August 24 $4^{\text {th }}, 1943$ (López-Rodríguez, 2013: 59; Muñoz-Encinar et al., 2013: 113). Concretely, two groups of people were registered as buried in graves nine and ten. In the logbook, the numbers five and three are written next to the date of these entries, which can be interpreted as the number of bodies buried in each grave. The group of three people buried in grave ten could correspond to the bodies found in Mass Grave 3 (López-Rodríguez, 2013: 59). According to the data published by Díaz (2011), these burials were the result of a confrontation between the mountain guerrillas and the Civil Guard, where six guerrilla men and a Civil Guard died (Díaz, 2011: 116) (Fig. 15; Fig. 16).

\section{THE REPRESSIVE STRATEGIES OF THE FRANCO REGIME}

After the failed coup of July $17^{\text {th }}, 1936$, the rebels carried out the conquest of uncontrolled territories by force.

The occupation of the territory was realized through the advance of the rebel column that moved towards Madrid. The column departed from Seville, passing through the region of Extremadura to arrive in the province of Toledo towards Madrid. In Extremadura, Badajoz and part of the east side of Cáceres would remain Republican.

Numerous authors such as Francisco Espinosa (2003), Paul Preston (2011) and others have pointed out that this column advanced with a clear plan of extermination through the imposition of terror (eliminating $1 \%$ of the

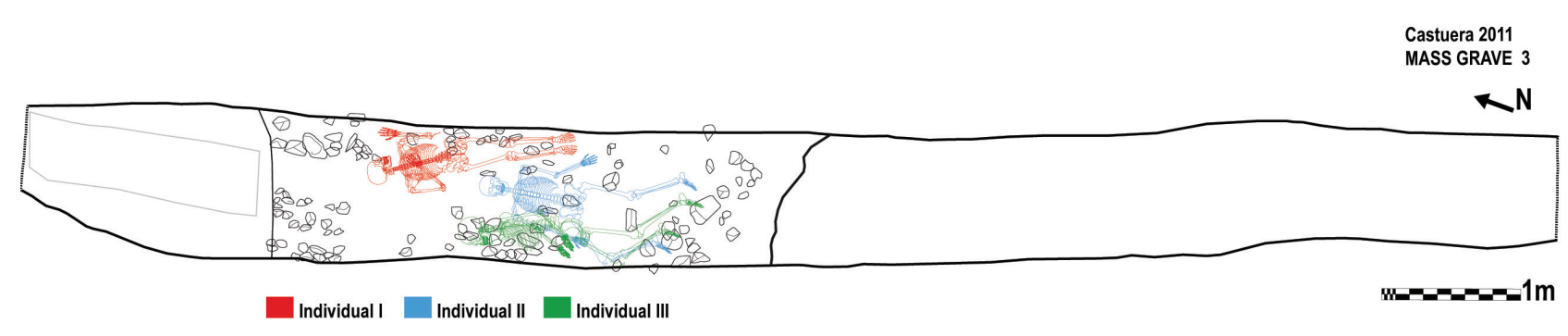

Figure 15: Drawing of the Mass Grave 3 of the Castuera Cemetery 
Castuera 2011

MASS GRAVE 3

R $N$
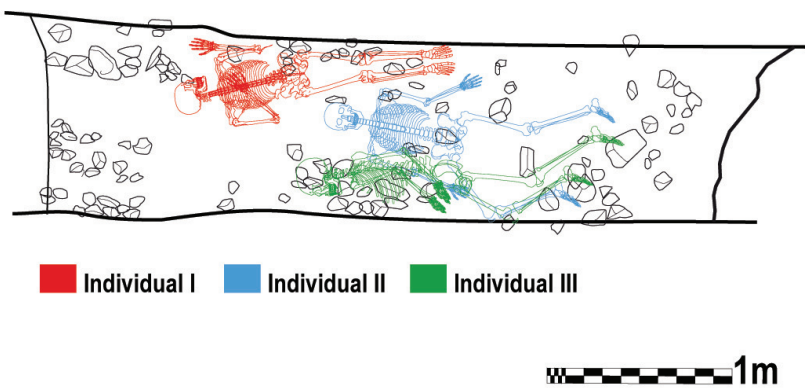

FIGURE 16: Drawing of the individuals who suffered repression and were buried in the Mass Grave 3 of the Castuera Cemetery

population), and the performance of systematic and organized executions. Military and paramilitary groups carried out the systematic and organized execution of all those involved in or connected to the Republic, as well as those in trade unions, political parties and left wing organizations in the occupied towns.

The columns that passed through Extremadura implemented early repressive strategies during the occupation of the territories controlled the rebel army. This strategy clearly made use of victims and the bodies as a mechanism to establish the terror among the population. The treatment of victims, the executions carried out and the cadavers that resulted from this violence would occupy, therefore, a very important part of the rebels' terror propaganda.

At this historical moment, mass and public executions were performed in many villages. Some of these had an exemplary character, where all the population was forced to attend.

After the victims' execution, the bodies and their treatment continued to be part of the language of terror. These practices correspond with the exposure and burning of the corpses, processes, which sometimes extended for several hours or even days. Another practice was the decision to not bury the bodies and to let them remain exposed and susceptible to the actions of carnivores and others vermin.

The visibility of these executions, the exposure of corpses, and the degrading treatment of victims, even after death, had a very strong psychological impact on civil society and a great effect on the establishment of a new order by force.

Some of the mass graves exhumed in the region such as those exhumed next to the Romanzal Stream in Llerena (Badajoz) and in the Mérida and Frenegal de la Sierra cemeteries belong to this moment (Chaves et al., 2014).

At the same time, the rebels also developed other strategies to eliminate people in the areas that supported the coup. In many cases, these strategies were carried out by new authorities who received help of paramilitaries groups like Falange. These tactics would be gradually generalized and stabilized after the occupation of the territories.

Among these strategies, the most common practice was that generally known as paseos. This procedure entailed the specific selection of people that had some kind of political activity or sympathy for the Republic. These people would be executed either individually or in groups in ditches by the road or in other places of terror.

In the practice of paseos, victims were usually arrested and taken from their homes to make declarations. After their arrest, sometimes they would remain temporarily in makeshift prisons where they were interrogated, tortured, humiliated and searched, their valuable possessions being subsequently stolen. Other times, victims were taken from their homes and executed directly. Within these repressive practices, there were widespread forms of public humiliation and martyrdom of the victims, who before being executed would be humiliated, tortured and mutilated as a mechanism of public derision.

The movement of victims from one locality to another to execute them, which aimed to extend the figure of the disappeared, was also part of the repressive strategy. In this way, there was a split between families and their knowledge regarding the details of their loved ones' the disappearance, their execution and the final whereabouts of their corpses.

Examples of these repressive strategies can be seen in case studies of the individual graves found in ditches in Villasbuenas de Gata.

We also find recurrent areas, spaces and landscapes used to conceal bodies in the rearguard. We are talking about the places of terror, enclaves generally outside of villages that were used during the Civil War to kill and hide the bodies of civilians. As part of these procedures, we can also include the use of mines and wells for burying people and the practice of throwing bodies into rivers or waterways. In these areas, victims were tortured publicly before death as part of the propaganda of terror. How bodies were used after death is less obvious.

As for the places of terror, we can show the example of Escurial, where the area known as Los Arenales was used during the War to kill and hide the bodies of many civilians from surrounding villages.

After the end of the War and the collapse of the fronts, new repressive strategies were implemented, in this case, associated with the mass arrest of thousands people. The Extremadura front, which had been significantly reduced after the 1938 offensive, resisted until March 1939, collapsing after the proclamation of the end of the War. It is at this point, when the process of imprisonment, consisting in the establishment and development of concentration camps and jails, began in Extremadura (González, 2006a; 2006b; 2007; 2013). The victims included a mix of prisoners originating from the recently defeated Republican army and thousands of civilians who had fled the military occupation.

This context conditioned the strategies developed in the area, due to the need to control and stabilize the territories that supported the Republic until the end of the War 
and to manage the thousands of prisoners in the first months of the postwar. Some of the tactics developed during the 1936 occupation would be implemented again and temporary Camps and prisons would be created, where the first systematic executions happened outside any judicial process.

After the occupation of the last areas, thousands of military and civilians were arrested, imprisoned and executed from April 1939 onwards. In these executions, the use of victims' bodies after death became once again another repressive strategy, part of the well-known propaganda of terror.

For example, several graves of civilians buried in the trenches of the second line of the Extremadura front of located in the town of Puebla de Alcocer (Chaves et al., 2014) correspond to this moment. Different groups of civilians were arrested in the town and locked in a provisional camp. They were later transported to the trenches and executed, leaving their bodies exposed for many days (Muñoz-Encinar, 2014). These details were also clearly noted in the oral testimonies collected in this area. They are, therefore, part of the traumatic memory that the community maintains in the present. Once again, we can see that the use of victims' bodies, both during and after executions, plays a crucial role in both the process of occupation and the socialization of terror.

After these first months, concentration camps and prisons were consolidated as the principal mechanism of social control in the area.

At this point it is important to ask: How would the regime manage such a large number of detainees? And more importantly, how would the regime proceed to classify, punish and dispose of such a large amount of people?

Two main methods of execution would coexist in different contexts of deprivation of liberty. In the concentration camps, after prisoners were classified, the most extended method of execution was the saca, multiple or individualized.

These sacas were generated by the classification activity that is based on the Military Police Information Service.

Along with this procedure, there were also the actions of retaliation conducted by the Falange that could access the camps with lists of prisoners that they had previously compiled. In addition to the arbitrary executions that were carried out, one has to add the poor living conditions that prompted deaths due to starvation and disease as part of the strategy of terror that took place inside the camps (Muñoz-Encinar et al., 2013:159). Prisoners were executed and their bodies were subsequently concealed in municipal cemeteries, selected areas near of the concentration camps and in the inside of mines. The graves exhumed in the cemetery of Castuera, where we documented several groups of prisoners from the concentration camp, are from this moment.

The second process of execution occurred when the repression seemed to normalize and the first court-martials were instructed. This process was applied in the occupied areas from 1937 and spread until 1938, reaching its peak in the early years of the dictatorship (C. Chaves,
2014). In these cases, the sentences were executed gradually, and victims' bodies were buried mainly in municipal or prison cemeteries.

Finally, after the end of the war, during the hard postwar period, the last resistance sought refuge in the mountains, where they combated Franco's Regime. So, the last repressive phase analyzed here concentrates on the regime's armed pursuit of guerrilla activity, a strategy which was carried out in rural areas by members of the Civil Guard who received additional support from members of the Falange (Muñoz-Encinar et al., 2013:160).

The armed resistance and guerrilla activity exercised by those who opposed the Regime was countered with a systematic plan of combat and elimination, in which the use of victims and their bodies played an important role. The propaganda of fear and terror was used once again to deter civilians from helping the armed resistance movement and encouraged neighbors to collaborate with complaints and denunciations.

In this period, many executions of guerrilla fighters occurred through the implementation of the Ley de Fugas (Law of Fugitives). In most cases, their bodies were exposed publicly. This public exposure of corpses was used as a strategy to implement fear and as a way to arrest possible dissidents that might recognize and identify the bodies of the guerrilleros. Some of the mass graves exhumed from this period have allowed us to contrast the forms of violence and torture in the arrest and treatment of the bodies of guerrilleros after their death. Burials that belong to this period include Mass Grave 3 in Castuera, from the first part of the 1940s, as well as the graves exhumed in Pozuelo de Zarzón and Cuacos de Yuste (Cáceres) from 1946 (Chaves et al., 2014).

\section{CONCLUSIONS}

The use of archeology and physical anthropology, as well as other disciplines, in the investigation of mass graves can help us to get closer to knowing the facts of the past, thereby giving us a critical view of our most recent traumatic past.

The treatment of victims during the Civil War and the first part of the dictatorship, and specifically those acts taking place before, during and after executions, are part of the how repressive practices were conceptualized and carried out by the perpetrators. Inside these repressive strategies, how bodies were used played a central role in the development of terror propaganda to be implemented by rebels.

Through archaeological research, we can obtain new evidence about the strategies used to eliminate people in the context of the Spanish Civil War and its aftermath. Moreover, we can delve into the particularities of Francoist violence as they are reflected in mass graves. We can also infer the existence of a directed and systematic plan for the elimination of all those people associated with the Republic or involved in trade unions, parties and others leftist organizations, as well as the elimination of 
all of those who were thought to be potential dissenters of the new established order.

The conceptualization of the systematic elimination of people is evident, as is the use of bodies as a tool of social control. In addition, how space is used in the repressive tactics employed by perpetrators also reflects different intentions. Through the stages described, within the different contexts analyzed between 1936 and 1946, the use of different spaces to articulate the language of repression is a constant.

In most cases, the landscape played a key role in choosing the location of the mass graves and in the elimination and/or concealment of the bodies contained within them. This utilization of space helped creating landscapes of terror that, in most cases, would continue to be part of the traumatic collective imagination of the community.

The use of the victims and their bodies underwent different states of visibility and invisibility depending on the interests of the perpetrators. These interests were connected to the time and context in which the executions occurred. Once the desired goal had been reached, the final state of these bodies was always their concealment and/or disappearance.

This fact implies, on the one hand, that evidence of crime was made to disappear and that victims continue to be considered disappeared. On the other hand, the repressive strategy extends to victims' families, in that they were unable to know the details of their loved one's death and the fact that they were unable to mourn. All of this is a result of the disappearance bodies.

In applying this analytic approach to the study of Francoist repression, we can provide evidence regarding the intentionality and systematicity that buttressed the development of an organized plan of elimination implemented during the Spanish Civil War and the Franco dictatorship. This approach can help us, from a scientific point of view, to provide new data that demonstrates the behaviors developed as part of a widespread and systematic attack against the civilian population.

\section{NOTES}

1. In the Presidential Order number $P R E / 2568 / 2011$, passed on September $26^{\text {th }}, 2011$, the Agreement of the Council of Ministers from September $23^{\text {rd }}, 2011$ was published. This agreement demanded that the Boletin Oficial del Estado publish a protocol regarding the carrying out of exhumations of mass graves containing victims of the Spanish Civil War and the dictatorship. BOE 232 of September $27^{\text {th }}, 2011$.

2. Catalán Deus, J., "El pueblo desentierra a sus muertos. Casas de Don Pedro, 39 años después de la matanza", Interviú, 15-21 June 1978, pp; 86-88.

3. Law number $2 / 1999$, passed on March $29^{\text {th }}, 1999$, is known as the Historical and Cultural Heritage of Extremadura Law. Law number $3 / 2011$, passed on February $17^{\text {th }}$, 2011, is known as the Partial Modification of the Historical and Cultural Heritage of Extremadura Law.

4. Decree 93/1997, known as the Regulation of Archaeological Activity in Extremadura.

5. Major Antonio Castejón Espinosa.

\section{REFERENCES}

Ayán Vila, Xurxo (2008) "El paisaje ausente: por una arqueología de la guerrilla antifranquista en Galicia". Complutum 19(2): 213-237.

Chaves Palacios, Julían (1995) La Represión en la provincia de Cáceres durante la Guerra Civil (1936-1939). Universidad de Extremadura. Cáceres.

Chaves Palacios, Julián (1997) La Guerra Civil en Extremadura. Operaciones militares (1936-1939). Editora regional de Extremadura, Mérida.

Chaves Palacios, Julián (2005) Guerrilla y franquismo: memoria viva del maquis Gerardo Anton (Pinto). Editora regional de Extremadura, Mérida.

Chaves, Julián; Chaves, Candela; Ibarra, Cayetano; Martín, Javier; Muñoz, Laura (2014) Recuperación de la Memoria Histórica en Extremadura. Balance de una década (2003-2013). Guerra Civil y Franquismo. Rayego, Zafra.

Chaves Rodríguez, Candela (2014) Justicia Militar y Consejos de Guerra en la Guerra Civil y el franquismo en la provincia de Badajoz: delitos, sentencias y condenas a desafectos. University of Extremadura, Department of History. $\mathrm{PhD}$ Thesis, unpublished.

Crossland, Zoe (2013) "Evidencial Regimes of Foresic Archaeology". Annual review of Anthropology 42:121-132.

Csordas, Thomas J. (2004) "Evidence of and for what?". Anthropology Theory 4 (4):473-80.

Daston, Lorraine (1994) "Marvelous facts and miraculous evidence in early modern Europe". In Questions of Evidence: Proof, Practice and Persuasion across the disciplines", edited by J. Chandler, AI. Davidson, H. Harrootunian. Uni. Chicago Press, Chicago: 243-74.

Díaz Díaz, Benito (2011) Huidos y Guerrilleros antifranquistas en el centro de España 1939-1955. Madrid, Ávila, Ciudad Real, Toledo, Cáceres y Badajoz. Tilia, Toledo.

Espinosa, Francisco (2003) La columna de la Muerte. El avance del ejército franquista de Sevilla a Badajoz. Crítica, Barcelona.

Ferrándiz Martín, Francisco (2007) "Exhumaciones y políticas de la memoria en la España contemporánea". Hispania Nova, 7: 621-640.

Ferrándiz Martín, Francisco (2011) Etnografias contemporáneas: Anclajes, métodos y claves para el futuro. Anthropos, Barcelona.

González Cortés, José Ramón (2006a) "Origen y desarrollo de los campos de concentración franquistas en Extremadura”. Revista de Estudios Extremeños, 1: 257-288.

González Cortés, José Ramón (2006b) "Prisioneros del miedo y control social. El campo de concentración de Castuera". Hispania Nova. Revista de Historia contemporánea, 6: 436-462.

González Cortés, José Ramón (2007) “El mundo concentracionario extremeño en el sistema represivo franquista: el campo de concentración de Castuera". In La depuración de funcionarios, maestros y otros colectivos "desafectos" en la provincia de Badajoz durante la Guerra Civil, J. García Pérez (coord.). Diputación de Badajoz, Badajoz: 167-228.

González Cortés, José Ramón (2013) "Prisioneros y esclavos del franquismo: Una visión a escala de lo concentracionario". En De la ocultación de las fosas a las exhumaciones. La represión franquista en el entorno del Campo de Concentración de Castuera, edited by Muñoz-Encinar, L; Ayán-Vila, X.; López-Rodríguez; A.D. AMECADEC, Santiago de Compostela: 29-40.

Gonzalez Ruibal, Alfredo (2007): Making things public. Archaeologies of Spanish Civil War. Public Archaeology, 6(4):203-26.

Gonzalez Ruibal, Alfredo (2008), Arqueología de la Guerra Civil española. Complutum, 19 (2): 11-20.

González Ruibal, Alfredo; Compañy, Gonzalo; Franco Fernández, Manuel Antonio; Laíño Piñeiro, Alejandro; Marín Suárez, Carlos, Martín Hidalgo, Patricia; Martínez Cañada, Indira, Rodríguez Paz, Anxo y Güimil Fariña, Alejandro (2010) Arqueología de un campo de Concentración. Informe de las excavaciones en el campo de Castuera (Badajoz, España), 1939-1940. Campaña de 2010. Memoria Arqueológica. CSIC. http://digital.csic.es/handle/10261/34407 
Gutiérrez Casalá, José Luis (2003) La Guerra Civil en la provincia de Badajoz. Represión republicano-franquista. Universitas, Badajoz.

Harris, Edward C. (1991) Principios de Estratigrafía Arqueológica. Crítica, Barcelona.

Ibarra Barroso, Cayetano (2010) "Fosas abiertas, heridas cerradas: investigación, localización, documentación y exhumación de fosas". In Guerra y Represión. Las Fosas de Escurial y Miajadas, edited by Olmedo, Ángel. Asamblea de Extremadura, Mérida: $121-154$

Ibarra Barroso, Cayetano (2010b) "Recuperación de la Memoria Histórica en Extremadura: Investigación, localización y exhumación de fosas". In Memoria e investigación en torno al setenta aniversario del final de la Guerra Civil, coordinated by Chaves Palacios, Julián. Diputación de Badajoz, Badajoz: 143-156.

Ibarra Barroso, Cayetano (2012) "Exhumaciones en Villasbuenas de Gata: Investigación, trabajos de campo y localización de fosas (2008-2009)". In Politica y Sociedad durante la Guerra Civil y el Franquismo: Extremadura, coordinated by Chaves Palacios, Julián. Diputación de Badajoz, Badajoz: 133-150.

López Rodríguez, Antonio Doroteo (2006) Cruz, bandera y caudillo. El campo de concentración de Castuera. CEDER-La Serena, Badajoz.

López Rodríguez, Antonio Doroteo (2009) Cruz, bandera y caudillo. El campo de concentración de Castuera, Badajoz. $2^{\mathrm{a}}$ ed. CEDER-La Serena, Badajoz.

López Rodríguez, Antonio Doroteo (2013). "Del campo de concentración y la prisión al cementerio: Breve introducción a la represión franquista en el Partido Judicial de Castuera". In De la ocultación de las fosas a las exhumaciones. La represión franquista en el entorno del Campo de Concentración de Castuera, edited by Muñoz-Encinar, Laura; Ayán-Vila, Xurxo; López-Rodríguez; Antonio Doroteo. AMECADEC, Santiago de Compostela: 41-61.

Martín Bastos, Javier (2013) Pérdida de vidas humanas a consecuencia de las prácticas represivas franquistas en la provincia de Badajoz (1936-1950). University of Extremadura, Department of History. PhD Thesis, unpublished.

Muñoz Encinar, Laura (2010) Informe arqueológico de las fosas comunes de la Guerra Civil de Villasbuenas de Gata, Cáceres. Dirección General de Patrimonio Cultural. Consejería de Educación y Cultura. Junta de Extremadura, unpublished.
Muñoz Encinar, Laura; García Vadillo, Francisco Javier (2010a)” Intervención Arqueológica en el Arroyo Romanzal: Exhumación de dos fosas comunes de la Guerra Civil". In Las Fosas del Romanzal de Llerena, edited by Ibarra Cayetano. Diputación Provincial de Badajoz. Badajoz: 97-132

Muñoz Encinar, Laura; García Vadillo, Francisco Javier (2010b) "Las fosas comunes de la Guerra Civil Española del arroyo Romanzal. La actividad represiva franquista en Llerena (Badajoz, España) durante los primeros días de ocupación. Contribución a la memoria". In "Recorriendo la Memoria. Touring Memory", edited by Almansa, Jaime. BAR International Series 2168: 5767, Oxford.

Muñoz Encinar, Laura; García Vadillo, Francisco Javier (2011) “La fosa común del Arroyo de Romanzal (Llerena, Badajoz): Nuevos datos para el registro arqueológico de la represión”. In Actas de las II Jornadas de Jóvenes en Investigación Arqueológica (Madrid, 6, 7 y 8 de mayo de 2009). JIA 2009, Tomo I. Edited by OrJIA. Libros Pórtico, Zaragoza: 253-259.

Muñoz Encinar, Laura; Rodríguez-Hidalgo, Antonio J. (2011) "Excavación arqueológica de las fosas comunes de Escurial". In Guerra y Represión. Las Fosas de Escurial y Miajadas edited by O1medo, Ángel. Asamblea de Extremadura, Mérida: 259-290.

Muñoz Encinar, Laura.; Ayán Vila, Xurxo.; López Rodríguez Antonio Doroteo (editor) (2013). De la ocultación de las fosas a las exhumaciones. La represión franquista en el entorno del Campo de Concentración de Castuera. AMECADEC, Santiago de Compostela.

Muñoz Encinar, Laura (2014). Memoria Arqueológica de exhumación de las fosas comunes de Puebla de Alcocer (Badajoz). INT 2012/052. Dirección General de Patrimonio Cultural. Consejería de Educación y Cultura. Junta de Extremadura, unpublished.

Olmedo Alonso, Ángel (2010) "Una Propuesta metodológica para la recuperación de la Memoria Histórica: Los "Campos de Trabajo" y la fosa del Romanzal". In Las fosas del Romanzal de Llerena. Edited by Ibarra, Cayetano. Diputación de Badajoz, Badajoz: 47-95.

Prada Marcos, María Encina; Etxeberría Gabilondo, Francisco; Herrasti Erlogorri, Lourdes; Vidal Encinas, Julio, Macías Pérez, Santiago; Pastor, F. (2003) "Antropología del pasado reciente: una fosa común de la Guerra Civil española en Priaranza del Bierzo (León)". Antropología y Biodiversidad 1: 431-446. 